\title{
The Impact of Organizational Factors on E-Business Adoption: An Empirical Analysis
}

\author{
Marta B. García-Moreno iD, Susana M. García-Moreno iD, \\ Juan Jose Nájera-SancheziD, Carmen De-Pablos-Heredero iD \\ Universidad Rey Juan Carlos (Spain) \\ marta.garcia@urjc.es,susanamaria.garcia@urjc.es,juanjose.najera@urjc.es,carmen.depablos@urjc.es
}

Received: June 2017

Accepted: February 2018

\section{Abstract:}

Purpose: Provide empirical validation of the model developed by García-Moreno, García-Moreno, Nájera-Sánchez and Pablos-Heredero (2016) on the factors influencing the adoption of e-business in firms.

Design/methodology/approach: Consideration is given to the method for measuring each one of the variables included in the model. Use has been made of the e-Business Watch database, which contains measures for the theoretical model's three categories: firm, technology, and environment. Multinomial logistic regression models have been provided.

Findings: The variables included have revealed significant statistical relationships for the model in question, although the intensity of the relationships differs. The variables related to the environment also reveal statistically significant relationships, whereby the attitude of trading partners appears to have a relevant and growing impact on e-business adoption.

Research limitations/implications: Data come from just one database: the e-Business Watch database/enriched data from alternative databases could be included.

Practical implications: The infrastructure of information and communications technologies (ICTs) is confirmed to be a determining factor in e-business development. Nevertheless, the effect of competitor rivalry has a more erratic influence that is encapsulated in a significant relationship in intermediate models, with a sharper increase in the likelihood of being in the category of customer-focused firms, and less internally focused.

Social implications: The human capital linked to ICTs is a driving force behind the adoption of these practices. Albeit with a more moderate effect, note should also be taken of the capacity for entering into relationships with third parties within the scope of ICTs, with significant effects that become more robust as they are tested in models that seek to explain the probability of recording higher levels of e-business adoption.

Originality/value: The article presents a first empirical analysis to apply the previous developed model published in this journal in 2016.

Keywords: e-business adoption, technologies, environment, management, model, multinomial regression analysis 


\section{Introduction}

This research sets out to validate the model developed by García Moreno et al. (2016) on the factors that impact upon the adoption of e-business by firms. Although there are prior studies in the literature that have used the existence, or not, of e-business practices as the measurement variable, this work is based on the construction of a more complex measure designed to describe in greater detail a firm's specific situation with regard to such practices. The variable used to explain the level of e-business adoption is therefore of a polytomous nature, that is, a nominal one with four categories.

The aim is therefore to provide empirical evidence of a relationship of dependency between a series of factors analysed in the literature and grouped together in the work by García Moreno et al. (2016) into three categories (firm, technology, and environment), and the level of e-business adoption, for the purpose of specifying whether the characteristics considered are favourable to, or are at least present in, those cases in which firms have adopted higher levels of e-business.

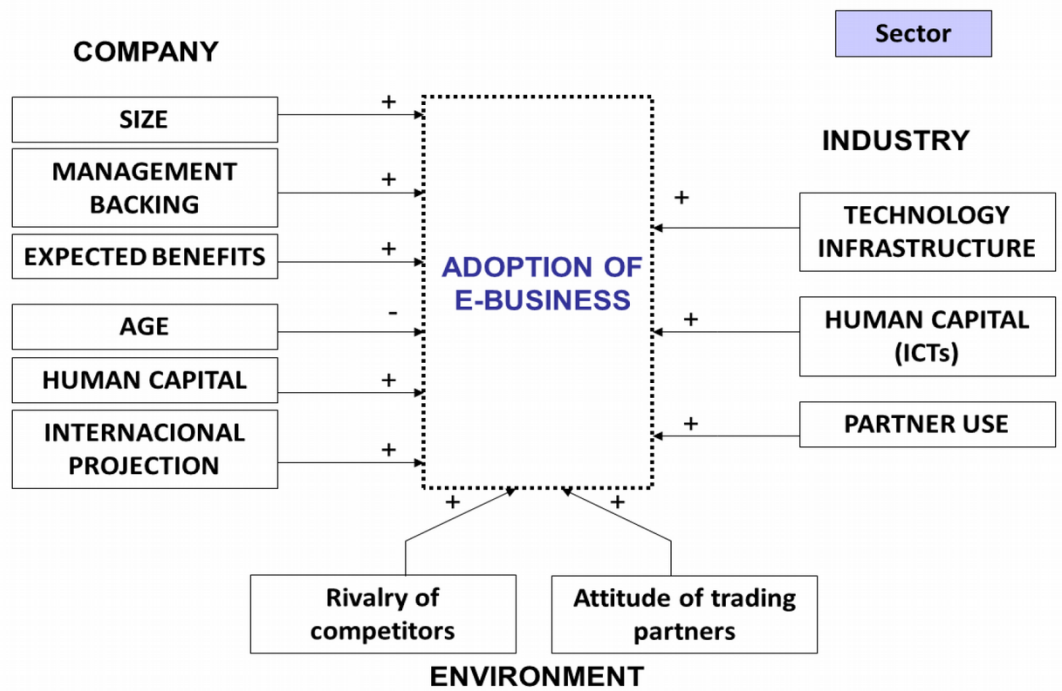

Figure 1. Factors conditioning e-business adoption (García Moreno et al., 2016)

\section{Research Design}

Once the different data sources had been assessed, the decision was made to measure the variables through the e-Business Watch database corresponding to 2006, precisely the year before the onset of the global economic crisis (so as to avoid its effects), compiled by Sectorial e-Business Watch (SeBW), a European observatory whose remit is to measure the adoption, implications, and effects of e-business in ten economic sectors in Europe. This database is being increasingly acknowledged within the international research community as a useful instrument for testing the new metrics of e-business. For example, Eurostat uses it to plan and develop its own survey on the use of ICTs by firms.

This database is very comprehensive on the adoption and use of ICTs in the industries studied, as it does not simply measure e-commerce or transactions (the volume of goods and services traded online), but also involves an assessment of the extent to which business processes are electronically interconnected and have been digitally integrated; in other words, it measures the level of e-business adoption/implementation. It combines aspects of quantitative and qualitative research. The quantitative analysis of firms' adoption of ICTs and e-business is based on representative surveys involving managers. The person responsible for ICTs, usually the head of IT, is the person involved. In other cases, above all in small firms without a separate IT division, the interview was held with the firm's managing director or owner. The study analysed solely those firms using IT systems for the pursuit of their businesses. 


\begin{tabular}{|c|c|c|}
\hline Question & Variable & $\begin{array}{l}\text { \# Question } \\
\text { eBW }\end{array}$ \\
\hline Does your firm have an intranet? & e-business & d1_1 \\
\hline Does your firm have knowledge management software? & e-business & d1_2 \\
\hline Does your firm use ERP? & e-business & d1_4 \\
\hline Does your firm have an SCM system? & e-business & d1_6 \\
\hline $\begin{array}{l}\text { Does your firm use the internet or other computer networks for } \\
\text { procuring goods or services from suppliers? }\end{array}$ & e-business & e1 \\
\hline Does your firm have its own website? & e-business & f1 \\
\hline Does your firm use CRM? & e-business & $\mathrm{f} 2$ \\
\hline $\begin{array}{l}\text { Can your firm's customers place orders via the internet or other data } \\
\text { networks? }\end{array}$ & e-business & $\mathrm{f} 4$ \\
\hline Headcount & Firm size & $\mathrm{z} 2 \mathrm{a}$ \\
\hline $\begin{array}{l}\text { Looking ahead to the next } 12 \text { months, will your firm's budget for ICTs be } \\
\text { increased, decreased, or remain the same? }\end{array}$ & Management's support & c2 \\
\hline Did your firm invest in ICTs in $2005 ?$ & Management's support & c3 \\
\hline $\begin{array}{l}\text { Did your firm decide to embrace e-business because you thought it } \\
\text { would give you a competitive advantage? }\end{array}$ & Profit expectations & h2_4 \\
\hline Date of the firm's incorporation & Firm's age & u3 \\
\hline$\%$ of employees with university degrees & Firm's human capital & u5 \\
\hline Which is your firm's main market: regional, national, or international? & Firm's international projection & u11 \\
\hline Internet access & Firm's technological infrastructure & a1 \\
\hline Does your firm have a local area network (LAN)? & Firm's technological infrastructure & a4_1 \\
\hline Does your firm have a Wireless LAN? & Firm's technological infrastructure & a4_2 \\
\hline Do employees have the option of remote access to internet services? & Firm's technological infrastructure & a5 \\
\hline Does your firm employ ICT professionals? & Firm's human capital in ICTs & b1 \\
\hline Does your firm regularly send staff for training in ICTs? & Firm's human capital in ICTs & b4 \\
\hline Has your firm ever outsourced ICT services? & Third-party development & b6 \\
\hline $\begin{array}{l}\text { Are your firm's IT solutions for sales and procurement based on an } \\
\text { application service provider (ASP)? }\end{array}$ & Third-party development & f12_3 \\
\hline $\begin{array}{l}\text { Did your firm embrace e-business because your competitors had already } \\
\text { done so? }\end{array}$ & Competitor rivalry & h2_1 \\
\hline $\begin{array}{l}\text { Did your firm embrace e-business because it's what your customers } \\
\text { expected? }\end{array}$ & The attitude of trading partners & h2_2 \\
\hline $\begin{array}{l}\text { Did your firm embrace e-business because it's what your suppliers } \\
\text { expected? }\end{array}$ & The attitude of trading partners & h2_3 \\
\hline NACE code & Sector & z1a \\
\hline
\end{tabular}

Table 1. Survey questions related to the model (based on the e-Business Watch questionnaire)

These surveys were administered over the phone, using a standardised system supported by a digital questionnaire. Overall, between April and May 2006, interviews were held with 14,000 firms from 10 economic sectors in EU Member States, with most of the countries belonging to the European Economic Area (EEA), while others were candidates.

The sample of firms was randomly selected from the respective population's industry in each country, with the aim being to comply with the minimum sample sizes in the strata regarding firm size for each country/industry cell. 
These strata involve a quota of $10 \%$ for large enterprises ( $>250$ employees), 30\% for medium-sized enterprises (50-249 employees), 25\% for small enterprises (10-49 employees), and 35\% for microenterprises ( $<10$ employees).

Once the data had been collected from the survey, the next step involved analysing the most appropriate ones for measuring each one of the model's variables. This meant choosing the questions that referred to each variable, analysing each one's suitability for achieving the corresponding goal.

Table 1 lists the survey questions used for drawing up the model's measures.

\subsection{Measuring the Model's Variables}

The dependent variable is e-business adoption. A literature review reveals different ways of measuring e-business adoption. Zhu, Kraemer and Xu (2006) measure the concept through an aggregate index: whether the firm has used the internet for each one of the seven activities in the value chain. These seven elements range from marketing, sales and after-sales service through to the coordination of the procurement and supply chain designed according to Porter's value chain model. Other studies have used a similar model for measuring the adoption of open systems (Chau \& Tam, 1997; Antonelli, 2014) and the adoption of technological innovation (Fichman, 2001). Nurmilaakso (2008) measures e-business adoption through an item contained in his data source, in which firms are asked the following question: can the firm sell or buy products via the internet or other IT networks, or does it use online technologies, other than e-mail, to cooperate with trading partners on the design of new products, foresee the demand for products, or manage stock capacity? Likewise, Zhu, Kraemer and Xu (2003) and De Haes and Van Grembergen (2015) measure adoption through a binary variable $(0,1)$, which classifies the firm as an adopter if it plans to implement e-business within the next two years. In turn, Lin \& Lin (2008) use eight variables on a six-point Likert-type scale, of which four are designed to measure the degree of internal integration of e-business within (1) the accounts and financial management, (2) stock control, (3) the processing of orders, and (4) the automation of the sales force, with the other four measuring the level of use of e-business in (1) the sharing of operational data with suppliers, (2) the sharing of operational data with customers, (3) the management of logistics with suppliers, and (4) the customer support service. Lin and Lee (2005) and Tong, Tak and Wong (2015) use a questionnaire in which they directly question firms about the level of e-business adoption they think they have achieved. These levels are classified as follows: (1) initiation, (2) propagation, (3) network, (4) business integration, and finally (5) business transformation. From our perspective, this measure is enormously subjective, as the classification is left in the hands of the manager involved in the survey, who might not have enough knowledge to classify the firm into one or other level depending on the applications available to them.

Based on the consideration made regarding the measures proposed in prior research, the level of a firm's e-business adoption was rated according to a set of dichotomous variables, with the aim being to observe and generate the adoption profiles of the different technologies linked to e-business. Specifically, the technologies that make up the measured adopted in this research are the intranet, knowledge management applications, ERP, SCM applications, the availability of customer relationship management (CRM) applications, the availability of a website, the use of e-procurement, and the pursuit of e-commerce.

The building of such an ambitious variable, with the large number of technologies involved, has not been a simple task, even more so considering the type of initial variables considered. There were numerous possible alternatives: from the use of a scale according to the number of technologies adopted (weighted or not), through to the approach via cluster analysis, with this latter alternative being the one finally chosen. The choice of this methodology was based on the absence of an objective criterion that might provide an accurate definition of the technologies carrying more or less weight in the concept to be measured. Generally speaking, and as we have already seen, the measures used in the literature consider a much smaller number of technologies and tend to give them equal importance, which is an approach we do not share.

The group analysis considered two basic, interrelated issues: one of an operational nature, and the other methodological. The first is due to the difficulties in classifying such a wide array of data as that used here: the bulk of the commercial applications used for the statistical processing of data do not involve tools with enough capacity to apply classification algorithms to qualitative data (in particular, dichotomous ones) for such a high number of cases. The second is related to the fact that the variables available for cluster analysis are dichotomous, which also 
restricts the type of algorithm that may be used. One of the few algorithms available for this analysis is called Monothetic Analysis (Kaufman \& Rousseeuw, 2005), based on the "association analysis" proposed by Williams and Lambert (1959). It is a type of hierarchical and divisive algorithm whose applicability is circumscribed to the case in which all the variables included in the analysis are binary, which is perfectly suited to the purpose of this research. The algorithm operates in a straightforward manner: given that all the variables included in the analysis are dichotomous, the first step is to divide all the elements that make up the analysis sample according to one of them, whereby the sample is divided into two. The next step involves dividing each group again based on another of the variables included in the analysis (which need not be the same one for both groups). The following steps are based on the same logic, making new divisions until either a group is created that consists of a single element or until there are no more variables for making further divisions within the group.

Thus considered, it is obvious that the algorithm's key aspect is the choice of the variable for making the divisions. The basic notion underpinning this choice is the search for the variable that best represents the whole.

The algorithm measures the degree of similarity using a relatively simple measure of association between dichotomous variables. For each variable, the table of contingency with all the others is measured, and the product of coincidences is obtained (i.e., the number of times in which the answers coincide), together with the product of discrepancies, (i.e., the number of times in which they differ). The products are then subtracted from one another, and the absolute value of that difference is the measure of similarity between the two variables. The sum of similarities calculated in this way is the measure of association. Given that the aim is for the variable used at each moment to be the one most representative of the whole, the one with the highest sum of similarities is chosen.

This algorithm is applied using the cluster package included in the $\mathrm{R}$ application, and which includes the algorithm described by Kaufman and Rousseeuw (2005). This software completes the process until one of the aforementioned limits is reached (single objective in a group or variables unable to generate a new division in any one of the groups). Following an analysis of the results that the different divisions provided, the choice was finally made to adopt the results obtained in the second iteration, producing four groups whose composition is summarised in Table 2 .

This classification algorithm has an additional advantage: the process determines the most pertinent variables for the division at each moment. This means that the results clearly show that the variable used for the first division is the availability of an intranet, which distinguishes between groups 1 and 2 on the one hand, and between groups 3 and 4 on the other. Clearly, groups 1 and 2 seem to adopt a lower level of e-business than groups 3 and 4 , although this aspect requires some clarification.

In the second step, the variable selected by the algorithm according to the aforesaid criteria is different for each group: while for the less advanced groups it is the availability of a website, the item used in the groups with a higher level of e-business was the availability of CRM. It should be noted, nonetheless, that although these are the variables that have been used directly, all the other variables take part in the group-forming process and, in fact, as the table shows, this configuration is reflected in certain particular traits in each group.

Insofar as the specific description of each group is concerned, special note should be taken of the sharp definition of the groups at the extremes: while group 1 records a clear lag regarding the mean in all the variables, group 4 is unequivocally above it. Accordingly, and for the purpose of this research, the firms belonging to group 1 are considered LATE MOVERS in terms of e-business, whereas the firms in group 4 are FIRST MOVERS. As is to be expected, the less advanced group is the most numerous ( $26.2 \%$ of the firms in the sample), while the group of First Movers in the smallest (9.9\% of the overall sample).

The boundary between groups 2 and 3 is not so clear. Thus, although group 2 records lower percentages (below the mean) than group 3 in the availability of intranet, knowledge management, ERP, SCM, and e-procurement (although the difference in this case is non-significant), it records higher percentages in CRM, and the availability of a website and e-commerce. This situation makes it difficult to decide upon a specific order between the two groups, because although a priori group 3 shows a slightly better situation, group 2 records better performances in what may be considered key technologies, especially within the scope of customer relations. So for our purposes here, we 
shall refer to group 2 as the one containing firms with a clear CUSTOMER FOCUS (CF) in terms of e-business, and to group 3 as the one whose firms have an INTERNAL FOCUS (IF).

\begin{tabular}{|l|r|r|r|r|r|}
\hline \multicolumn{1}{|c|}{ Group } & 1 & 2 & 3 & 4 & Total \\
\hline Number of companies & 3391 & 4713 & 3556 & 1283 & 12943 \\
\hline Percentage of companies & $26.2 \%$ & $36.4 \%$ & $27.5 \%$ & $9.9 \%$ & $100.0 \%$ \\
\hline \multicolumn{3}{|r|}{} & \multicolumn{3}{|c|}{$\%$ of affirmative answers } \\
\hline Intranet & $0.0 \%$ & $0.0 \%$ & $100.0 \%$ & $100.0 \%$ & $37.4 \%$ \\
\hline Knowledge Management & $5.6 \%$ & $8.1 \%$ & $17.0 \%$ & $35.5 \%$ & $12.6 \%$ \\
\hline ERP & $9.8 \%$ & $16.1 \%$ & $28.5 \%$ & $52.8 \%$ & $21.5 \%$ \\
\hline SCM & $8.1 \%$ & $10.2 \%$ & $17.3 \%$ & $33.6 \%$ & $13.9 \%$ \\
\hline CRM & $3.8 \%$ & $11.4 \%$ & $0.0 \%$ & $100.0 \%$ & $15.1 \%$ \\
\hline Website & $0.0 \%$ & $100.0 \%$ & $77.4 \%$ & $94.2 \%$ & $67.0 \%$ \\
\hline e-procurement & $39.7 \%$ & $59.7 \%$ & $61.8 \%$ & $83.3 \%$ & $57.4 \%$ \\
\hline e-commerce & $8.9 \%$ & $36.6 \%$ & $27.4 \%$ & $53.7 \%$ & $28.5 \%$ \\
\hline
\end{tabular}

Table 2. Group composition

\subsection{Measuring the Independent Variables}

There now follows a description of the way in which the independent variables are measured. These variables have been proposed as factors with an influence on e-business adoption. As verified in the work by García Moreno et al. (2016), the empirical study has 11 independent variables.

\subsubsection{Measuring Firm Size}

One of the classical topics in the literature on the adoption of innovations, which also extends to e-business, is the influence of firm size, with hypotheses formulated in both directions, as noted by García Moreno et al. (2016).

Accordingly, different authors have measured firm size. Thus, Hong and Zhu (2006), Zhu et al. (2006), Bayo-Moriones and Lera-López (2007), Tan, Tyler and Manica (2007) and Teo (2007) measure size in terms of a firm's overall headcount, while Kowtha and Choon (2001), Bertschek and Fryges (2002), Zhu et al. (2003), Correa, Fernandes and Uregian (2010) and Tong et al. (2015) use the logarithm of headcount.

Our research measures firm size as the natural logarithm of headcount. The transformation into a logarithm tends to be used to avoid skewed data (Thong, 1999; Zhu et al., 2003; Lucchetti \& Sterlacchini, 2004). The choice of this metrics is based on the availability of the measure and the attempt to temper the series' tendency. The variable to be used is expressed as follows:

$$
\operatorname{SIZE}=\operatorname{Ln}(\mathrm{N})
$$

where $\mathrm{N}$ is the firm's headcount in 2006.

\subsubsection{Measuring Top Management's Support in the Firm}

Sundry authors measure the interest managers show in adopting different technologies through questionnaires sent to the firm with various items using a Likert-type scale. Thus, Teo, Tan and Wong (1998) guide the questions toward internet adoption, Beatty, Shim and Jones (2001) toward website adoption; Soliman and Janz (2004) and Zhu et al. (2006) toward the adoption of e-business; and Grandon and Pearson (2004), Molla and Licker (2005), and Kerzner (2013) toward the adoption of e-commerce. The items that these authors use for their metrics include several very general ones in which questions are asked directly about top management's interest in adopting the technology. Others are designed to gauge the importance that management gives to that technology, while others 
explore whether top management considers the adoption to be strategic, or even whether it believes there are competitive advantages to be gained through its implementation. In addition, there are also items that measure the level of risk that management perceives in the technology, as well as whether it discerns too many changes in the organisation, and even difficulties when integrating the new technology with the firm's strategy.

Jarvenpaa and Ives (1991) perform a more thorough and in-depth measurement, including more than 15 items designed to determine this variable, which leads to a problem of size stemming from the use of a high number of items. All these measures are, in our opinion, prone to a very high degree of subjectivity, as rather than the real support from top management, they measure the perception management has of the technology to be adopted. By contrast, Hong and Zhu (2006), Teo (2007), and Jeston and Nelis (2014) measure top management's support as the percentage of the budget earmarked for ICTs, which avoids the problem we have just mentioned.

In order to measure this support here, we have considered two variables: on the one hand, the dichotomous INVESTMENT $(0,1)$, which differentiates between those firms that invested in these technologies in the previous year and those that did not. To be effective, and considering the speed at which this field develops, any commitment in this matter has to be backed by investments. Accordingly, this variable is considered to faithfully reflect this commitment. On the other hand, another variable called INVFUTURE has been considered, whereby those firms in the database disclosed their future intentions regarding investment in ICTs, distinguishing between an increase, a decrease, or no change. Once again, this statement of intentions made by the firms transmits the future outlook for the previous measure and is of relevance in the measurement of management support. Therefore:

INVESTMENT $=1$ if the firm has invested in ICTs in the previous year, and

INVESTMENT $=0$ otherwise

INVFUTURE $=0$ if the investment is set to increase in the future

INVFUTURE $=1$ if the investment is set to decrease in the future

INVFUTURE $=2$ if the investment is set to remain unchanged in the future

These two variables were used to measure management support MANSUPP, which involved considering three levels: low, medium and high. The high level contained all those firms that invested in ICTs the prior year and disclosed their intention of increasing this investment in the following year. In our opinion, these are the only firms showing full commitment to ICTs, insofar as they consider them to be a resource that has not only called for investment but is also expected to grow in the future. The medium level contains those firms that plan to increase their investment over the coming year but have not invested in the previous year, or those that having done so in the prior period have chosen to make no change (no increase). Only the medium level is applicable in this case because there is a certain discontinuity in their approach. Finally, there are all the remaining firms, which either because they have not invested or because their investment has remained unchanged or been reduced, or because they have invested but plan to reduce their future investment, have been deemed to have a lower commitment to ICTs.

The variable to be used is expressed as follows:

If INVESTMENT $=1$ and INVFUTURE $=0$ then MANSUPP $=$ "High"

If INVESTMENT $=0$ and INVFUTURE $=0$ then MANSUPP $=$ "Medium"

If INVESTMENT $=1$ and INVFUTURE $=2$ then MANSUPP $=$ "Medium"

If INVESTMENT $=0$ and INVFUTURE $=1$ then MANSUPP $=$ "Low"

If INVESTMENT $=0$ and INVFUTURE $=2$ then MANSUPP $=$ "Low"

If INVESTMENT $=1$ and INVFUTURE $=1$ then MANSUPP $=$ "Low" 


\subsubsection{Measuring Profit Expectations}

According to its very nature, the following variable needs to be qualitatively measured in an eminently subjective manner. It involves a perception, the expectation, of potential earnings, which dismisses any possibility of objective measurement. Throughout the literature there are cases of metrics involving several items in questionnaires designed to capture the perception that a firm has regarding the potential earnings to be obtained by adopting technology. Authors such as Teo et al. (1998), Beatty et al. (2001), Grandon and Pearson (2004), Lin and Lin (2008), and Wang and Ahmed (2008) perform their measurements in this way.

In turn, Mehrtens, Cragg and Mills (2001) use qualitative case-study methodology to ask the firms under study about the types of earnings they hope to obtain by adopting the internet, while Iacovou, Benbasat and Dexter (1995), Chwelos, Benbasat and Dexter (2001), and Bloom, Propper, Seiler and Van Reenen (2015) distinguish between direct and indirect earnings.

In our research, this variable is measured through the item EXPECTEARN, which will indicate whether the firm has decided to embrace e-business because it expects this will give it a competitive advantage. This variable takes the value 1 in an affirmative case, and 0 otherwise. Therefore:

EXPECTEARN $=1$ when the firm decides to embrace e-business because it expects this will give it a competitive advantage.

EXPECTEARN $=0$ when this was not an important factor in its decision.

\subsubsection{Measuring Firm Age}

The next question to be considered involves measuring a firm's age. Kowtha and Choon (2001) measure it as the logarithm of the months since the firm was incorporated, while Bertschek and Fryges (2002) and Chae, Koh \& Prybutok (2014) use an item that may take three values, with the aim being to classify firms according to the number of years they have been trading (fewer than three, between four and seven, and more than seven).

With a view to measuring this characteristic, this research has adopted the variable AGE, of an ordinal nature that classifies firms according to their date of incorporation, being stated as follows:

$\mathrm{AGE}=0$ if the company was founded before 1981

AGE $=1$ between 1981 and 1996.

AGE $=2$ between 1997 and 2002.

AGE $=3$ between 2003 and 2006.

\subsubsection{Measuring a Firm's Human Capital}

Bertschek and Fryges (2002) measure this variable through employees' university qualifications, as do Bayo-Moriones and Lera-López (2007). In turn, Vilaseca, Torrent, Meseguer and Rodriguez (2007), Rodríguez Ardura, Meseguer-Artola and Vilaseca-Requena (2007), and Buabeng-Andoh (2012) focus their metrics on the firm's management, based on their level of studies.

This study considers that the qualitative difference lies in having, or not, university qualifications: so the variable chosen to reflect the level of studies among human capital (HUMANCAP) is the percentage of employees with a five-year degree (graduates and full engineers) and a three-year degree (diplomas or technical engineers). Therefore:

HUMANCAP $=\%$ employees with a university qualification.

\subsubsection{Measuring a Firm's International Projection}

Bertschek and Fryges (2002) and Zhou (2011) use a quantitative variable that contains the turnover recorded by the firm's exports. Likewise, Zhu et al. (2006) use an item that measures the percentages of the firm's sales and purchases in markets abroad. Bayo-Moriones and Lera-López (2007) and Abebe (2014) use a binary variable to classify firms according to the main markets in which they operate, either internationally, nationally, or regionally. 
We have measured this variable here using an ordinal variable called PROYECTINT $(1,2,3)$, which classifies firms according to their main market, distinguishing between three ambits: regional, national and international. Therefore:

PROYECTINT $=1$ if the firm's main market is regional

PROYECTINT $=2$ if it is national

PROYECTINT $=3$ if it is international

\subsubsection{Measuring a Firm's Technological Infrastructure}

There are a number of different approaches to this variable's metrics. There are those authors who focus more on verifying whether the applications to be adopted will be compatible with the firm's current technology and systems, such as Beatty et al. (2001) and Hong and Zhu (2006), while others such as Lin and Lin (2008) and Patil and Kant (2014) base their metrics more on the technologies available to the firm.

Based on this latter approach, Molla and Licker (2005) measure the variable through a series of items in which they ask each enterprise about the availability of LAN and a wide-area network (WAN), a broadband internet connection, and the flexibility of their current systems, among others. Similarly, Wang and Ahmed (2008) use two items that reflect whether the firm has sufficient resources, and whether the firm's current technology systems are compatible with e-commerce.

Finally, note should be taken of the metrics applied by Zhu et al. (2006) and Camisón and Villar-López (2014), in which they use two items to measure the technologies a firm uses and the number of PCs the firm has.

In order to measure a firm's technological infrastructure within the scope of ITs, we have used three dichotomous items: availability of an internet connection (CONNECTION), availability of LAN (cable or wireless), and the possibility employees have to remotely access the firm's information systems (REMOTE). The variable finally used, CAPATEC, was constructed by adding up each firm's affirmative answers, whereby the measure's possible values ranged from zero, when all the answers were negative, to three, when the firm had all three of these options. Therefore:

CONNECTION $=1$ if the firm has an internet connection, and CONNECTION $=0$ otherwise.

$\mathrm{LAN}=1$ if it has such a network, and LAN $=0$ otherwise.

REMOTE $=1$ if there is remote access to the systems, and REMOTE $=0$ otherwise.

CAPATEC $=$ CONNECTION + LAN + REMOTE

\subsubsection{Measuring a Firm's Human Capital in ICTs}

Mehrtens et al. (2001) measure employees' level of technological expertise, and Bertschek and Fryges (2002) use the number of ICT specialists employed in the firm, coinciding with the measurement of this recourse proposed by Zhu et al. (2006). In turn, Ranganathan, Dhaliwai and Teo (2004) measure this variable in terms of management's knowledge of technology.

Lin and Lee (2005), Molla and Licker (2005), and Stam, Arzlanian and Elfring (2014) measure it through the level of expertise and experience in e-business among the firm's employees. In turn, Lin and Lin (2008) and Greene, Brush and Brown (2015) use an item that measures employees' level of specialisation in ICTs.

This means that both the availability of employees who specifically oversee the management of this technology in the firm (PROFICT), and the training effort the firm makes for its use among its workforce (TRAINICT) are items that can fairly accurately reflect the firm's situation in this ambit. These two dichotomous variables $(0,1)$ were therefore used to construct a variable (HUMANCAPICT), which as in the case of technological infrastructure is based on the sum of affirmative answers, ranging between zero and two: zero if the firm does not have any experts or arrange specific training, and two if it has specific staff for technologies and it organises staff training in this field. Therefore:

PROFICT $=1$ if it has ICT staff, and PROFICT $=0$ otherwise. 
TRAINICT $=1$ if it organises training in ICTs, and TRAINICT $=0$ otherwise.

HUMANCAPICT $=$ PROFICT + TRAINICT

\subsubsection{Measuring Third-Party Development}

Several authors in the literature have measured this variable in different ways. Thus, Loh and Venkatraman (1992) measure it through the cost the firm has incurred by outsourcing information systems. Poppo and Zenger (1998) use the percentage of ICTs the firm has outsourced, and Arnett and Jones (1994) and Lacity and Willcocks (2012) measure it through the outsourced functions of information systems. For their part, Hong and Zhu (2006) measure this variable according to the level of outsourcing through technology partners in IT-related areas.

The variable representing the level of third-party development included here has therefore involved two main items: the use of outsourcing (OUTSOUR), understood as the outsourcing of services linked to ICTs in the firm, and the use of an Application Service Provider (ASP). Both variables are dichotomous $(0,1)$, as is the resulting variable (PARTNERUSE). This variable will take the value (1) provided that the firm performs one or other activity (outsourcing or ASP). Therefore:

OUTSOUR $=1$ if in the past year the firm has outsourced ICT services, and OUTSOUR $=0$ otherwise.

$\mathrm{ASP}=1$ if it uses services in ASP mode, and ASP $=0$ otherwise.

We consider this variable when either of the two items, OUTSOUR or ASP, have an affirmative response, that is $=1$. This provides the following results:

If OUTSOUR $=1$ and $/$ or ASP $=1$, then PARTNERUSE $=1$, otherwise PARTNERUSE $=0$

The reason for this construct is that the use of one or other type of contract is different, with the relevant aspect being the existence of relationships with technological partners within the field of technologies.

\subsubsection{Measuring Competitor Rivalry}

A review of the literature has revealed different ways of measuring and focusing this variable, although we may basically refer to two main approaches; on the one hand, the number of competitors in the industry, and on the other, the impact on the firm when its competitors adopt a technology.

Accordingly, Kowtha and Choon (2001), Bertschek and Fryges (2002), Zhu et al. (2003), Soliman and Janz (2004), Grandon and Pearson (2004), and Wang and Ahmed (2008) base their metrics on the influence that competitors' movements have on the firm's decision to adopt, through different items featured on questionnaires (Likert-type scale). Likewise, Mehrtens et al. (2001) and Yusuf, Gunasekaran, Musa, Dauda, El-Berishy and Cang (2014) measure the variable in the same way, although their work is based on the study of different firm cases.

Lin and Lin (2008) use two items to measure the pressure exerted by competitors on the decision to adopt e-business, following the studies by Premkumar and Ramamurthy (1995). On the other hand, Bayo-Moriones and Lera-López (2007) measure competitor rivalry as the number of competitors a firm has, as do Rodríguez-Ardura et al. (2007), who also distinguish between the firm's competitors at European and global level, and Vilaseca et al. (2007), who measure competitors in the USA and in the rest of the world.

Zhu et al. (2006) measure the variable through three items that reveal the extent to which the firm is affected by its competitors, following Porter (1985) and Zhu et al. (2003). Along these same lines, Xu, Zhu and Gibbs (2004) and Subramanian, Gunasekaran, Yu, Cheng and Ning (2014) measure the extent to which a firm is influenced by its local, national, and international competitors.

Another way of measuring this item, as reported in the literature, is to verify whether firms keep an eye on their competitors' initiatives, monitoring their movements (Ranganathan et al. 2004), which shows whether the firm is in some way influenced by them.

Teo et al. (1998) base their metrics on the type of competitive strategy the firm pursues and the number of competitors in its operating industry. 
Following the above-mentioned studies, which base their metrics on the influence competitors exert on the decision on whether or not to adopt, our work uses one item to measure this variable, where despite being a subjective measure it is understood to provide us with enough information to make the evaluation. This measure involves a dichotomous variable RIVALCOMP $(1,0)$ based on a single item that explores the influence that competitors have on the firm's incorporation of e-business activities. Therefore:

RIVALCOMP $=1$ if the firm decides to embrace e-business because its competitors have already done so.

RIVALCOMP $=0$ if the firm decides not to embrace e-business because its competitors have already done so.

\subsubsection{Measuring the Attitude of Trading Partners}

This variable has been measured both quantitatively and qualitatively. Among the forms of qualitative measurement, there are many authors who seek to measure this variable through different items on their questionnaires, asking questions to find out whether the firm's customers and suppliers expect it to adopt the technology in question. Special mention should be made in this case of Mehrtens et al. (2001), Wang and Ahmed (2008), and Park and Lee (2014).

Another important point to be noted in the measurement of this variable involves the studies that focus on the influence that suppliers and customers exert over the firm, stressing that the greater their negotiating power, the greater the pressure or submission to them the firm will face. Chwelos et al. (2001) and Lin and Lin (2008), following the former, measure the influence of trading partners by using items on whether the partners have requested or recommended the use of e-business tools, as well as on the technical level and expertise of customers and suppliers. Likewise, Soliman and Janz (2004) use a series of items to assess whether the firm's main trading partner is the one that takes the initiative and makes the decisions in their dealings.

Nevertheless, Molla and Liker (2005) and Lin, Huang, Jalleh, Liu and Tung (2010) take a different approach when measuring this variable, noting that it is the firm's own opinion on whether their trading partners are qualified or prepared for business over the internet that informs the decision in this variable.

Ranganathan et al. (2004) measure the variable through four items taken from the study by Purvis, Sambamurthy and Zmud (2001), focusing on the level of technology use among trading partners, as do Park and Lee (2014); so the greater the intensity of IT among customers and suppliers, the more favourable their attitude toward technology.

As noted earlier, there are also authors who have sought to measure the variable quantitatively. These include the work by Iacovou et al. (1995), whose case study asked the firms in question about their number of customers and suppliers, exploring the matter further until they knew the type of trading partners in terms of size and international projection.

In order to measure this variable and following authors such as Mehrtens et al. (2001), Wang and Ahmed (2008), and Park and Lee (2014), the combination has been split into two items: the firm's decision to embrace e-business in response to customer expectations CUSTOMERS $(0,1)$ and suppliers SUPPLIERS $(0,1)$. Both variables are dichotomous, taking the value zero when there is no such influence, and one otherwise. Based on these two variables, a single variable was constructed called COMPARTNERSDISP, which takes the value zero when both answers are negative, and one otherwise.

CUSTOMERS $=1$ if the decision was made to embrace e-business because it is what customers expected, and CUSTOMERS $=0$ otherwise.

SUPPLIERS $=1$ if the decision was made to embrace e-business because it is what suppliers expected, and SUPPLIERS $=0$ otherwise.

Therefore:

If SUPPLIERS $=1$ or CUSTOMERS $=1$, then COMPARTNERSDISP $=1$, otherwise COMPARTNERSDISP $=0$.

The reason for constructing the variable in this way is that customer relations may be very important for a firm and much less so those with suppliers, and vice versa. If they are not important, there is no point in making a negative 
assessment of behaviour that is not pursued because it is not required. Nonetheless, if none of them is relevant, it is understood that there is no favourable attitude, and so the value is zero.

\subsubsection{Measuring the Control Variable}

\begin{tabular}{|c|c|c|}
\hline Variable & Indicator & Metrics \\
\hline SIZE OF THE FIRM & SIZE & Scale variable. Natural logarithm of the headcount over the past year. \\
\hline $\begin{array}{l}\text { MANAGEMENT } \\
\text { SUPPORT }\end{array}$ & MANSUPP & $\begin{array}{l}\text { Ordinal category variable, with three different levels: } \\
\text { Low: not currently investing and upholding or reducing its future } \\
\text { behaviour; or currently investing but reducing its future investment. } \\
\text { Medium: not currently investing and increasing its investment over the } \\
\text { next business year; or currently investing and upholding its future } \\
\text { behaviour. } \\
\text { High: Investing in the current business year and increasing its } \\
\text { investment over the coming business year. }\end{array}$ \\
\hline $\begin{array}{l}\text { PROFIT } \\
\text { EXPECTATIONS }\end{array}$ & EXPECTEARN & $\begin{array}{l}\text { Dichotomous variable. } \\
\text { 1: if the firm decides to embrace e-business because it expects to gain } \\
\text { a competitive advantage. } \\
0 \text { : when this has no major bearing on its decision. }\end{array}$ \\
\hline AGE OF THE FIRM & AGE & $\begin{array}{l}\text { Ordinal category variable. } \\
\text { 0: Incorporated before } 1981 \\
\text { 1: Incorporated between } 1981 \text { and } 1996 \\
\text { 2: Incorporated between } 1997 \text { and } 2002 \\
\text { 3: Incorporated between } 2003 \text { and } 2006\end{array}$ \\
\hline HUMAN CAPITAL & HUMANCAP & $\begin{array}{l}\text { Scale variable. Percentage of employees with three- and five-year } \\
\text { degrees over the total headcount in the past year. }\end{array}$ \\
\hline $\begin{array}{l}\text { INTERNATIONAL } \\
\text { PROJECTION }\end{array}$ & PROYECTINT & $\begin{array}{l}\text { Ordinal category variable. Reflecting the firm's main market: } \\
\text { 1: Regional } \\
\text { 2: National } \\
\text { 3: International }\end{array}$ \\
\hline $\begin{array}{l}\text { TECHNOLOGICAL } \\
\text { INFRAESTRUCTURE }\end{array}$ & CAPATEC & $\begin{array}{l}\text { Scale variable, with values ranging between } 0 \text { and } 3 \text { depending on the } \\
\text { number of technologies the firm has in terms of the following: } \\
\text { internet connection, availability of intranet, and option for employees } \\
\text { to remotely connect to the firm's network }\end{array}$ \\
\hline $\begin{array}{l}\text { HUMAN CAPITAL } \\
\text { ICT }\end{array}$ & HUMANCAPICT & $\begin{array}{l}\text { Ordinal category variable. } \\
\text { 0: no dedicated ICT staff and no specific training in ICTs. } \\
\text { 1: Dedicated ICT staff or specific training in ICTs. } \\
\text { 2: Dedicated ICT staff and specific training in ICTs. }\end{array}$ \\
\hline $\begin{array}{l}\text { THIRD PARTY } \\
\text { DEVELOPMENT }\end{array}$ & PARTNERUSE & $\begin{array}{l}\text { Dichotomous variable. } \\
\text { 1: Use of outsourcing and/or ASP. } \\
0: \text { No use of outsourcing or ASP. }\end{array}$ \\
\hline $\begin{array}{l}\text { COMPETITOR } \\
\text { RIVALRY }\end{array}$ & RIVALCOMP & $\begin{array}{l}\text { Dichotomous variable. } \\
\text { 1: if the firm decides to embrace e-business because its competitors } \\
\text { have already done so. } \\
0: \text { when this has no major bearing on its decision. }\end{array}$ \\
\hline $\begin{array}{l}\text { ATTITUDE OF } \\
\text { TRAINING } \\
\text { PARTNERS }\end{array}$ & COMPARTNERSDISP & $\begin{array}{l}\text { Dichotomous variable. } \\
\text { 1: if the firm decides to embrace e-business because this is what its } \\
\text { customers and/or suppliers expect. } \\
0 \text { : when this has no major bearing on its decision. }\end{array}$ \\
\hline SECTOR & SECTOR & $\begin{array}{l}\text { Nominal category variable. } \\
\text { Industry } \\
\text { Construction } \\
\text { Services }\end{array}$ \\
\hline
\end{tabular}

Table 3. Metrics of the independent variables used in the analysis 
To end, this section proposes the measure of the industry in which the surveyed firm operates as the model's sole control variable. This variable is considered for the purpose of knowing whether the firm's operating industry may be altering the relationship between the dependent variable and the independent ones.

Given the broad array of industries, and in order not to assign too much weight in the explanatory models developed subsequently, a cap has been put on the number of categories for the variable finally adopted, distinguishing solely between industrial companies, those linked to the building sector, and service provider firms.

It would obviously have been pertinent to make this classification using a criterion more closely related to e-business, which is the topic addressed in this $\mathrm{PhD}$ dissertation. Nevertheless, the limited availability of information in public registers for characterising industries has made it impossible to undertake this task.

To recap, Table 3 describes how each one of the dependent variables has been measured for use in the statistical work.

Two decisions were made prior to the model's estimation. Firstly, regarding the treatment of lost variables, it was noted that in general the proportion of observations that responded to this pattern did not exceed $5 \%$ of the sample. Considering that the database used has many more entries than those required for providing a representative sample for infinite populations, the decision was made to follow the usual procedure of deleting cases from the list, which means omitting from the model those entries with missing data.

Secondly, with a view to eliminating any potentially atypical cases that may be having a definitive impact on the analysis's reliability, the procedure propounded by Orme and Combs-Orme (2009) was followed. This process assumes there are no well-developed methods for defining atypical cases for the multinomial logistic regression (Hoffmann, 2004; Hosmer, Lemeshow \& Sturdivant, 2013). In order to conduct this task, therefore, several binary logistic regressions were performed, recoding the dependent variable into dichotomous variables that contain just two categories, considering all the values to be missing.

A total of six models were fitted, being as many as the possible combinations of the categories of the dependent variable, taken two by two. Each model involved the estimation of its standardised residuals and Cook's distance (D) measure, with the aim of locating the outliers and possible observations whose influence might lead to biases in the model. All those observations whose standardised residuals were higher than 3 or lower than -3 were discarded, as were those observations whose Cook's D exceeded unity, following the criterion propounded by Cohen, Cohen, West and Aiken (2003) and Norusis (2007). This process was repeated reiteratively until all the observations that failed to meet either one of these two conditions had been discarded, which ensures a database free of atypical cases.

\section{Estimating the Final Model}

Once the partial analyses had been conducted, and taking into account the results obtained, the full model's fit has been analysed, including all the variables considered in the theoretical framework. As in the previous stage, the multinomial logistic regression models have been fitted by adopting as reference category firstly the group of Late Movers from the e-business variable. The general tests on the model's goodness of fit provided satisfactory results, with deviation and Pearson's tests whose significance was well above 0.05 , the threshold below which the model is not considered to fit the data properly.

On the other hand, regarding the explanatory capacity of the models considered, adopting the classic models proposed for this type of analysis provided pseudo- $\mathrm{R}^{2}$ coefficients with values ranging between 0.493 (Nagelkerke) and 0.240 (McFadden). These values may be considered somewhere between satisfactory and very satisfactory, and the same may be said for the correct percentage of classification.

Regarding the verifications of the likelihood ratio, which determine whether the independent variables included in the model are important in the explanation of the dependent variable, the tests provided more than satisfactory results for the whole models, with all the variables included as significant at a 99\% confidence level.

The results for this first model are summarised in Tables 4-8. 


\begin{tabular}{|l|r|r|r|r|}
\hline & \multicolumn{1}{|c|}{-2 log-likelihood } & Chi squared & \multicolumn{1}{c|}{ gl } & Sig. \\
\hline Only the intersection & 24867.166 & & & \\
\hline Final & 18823.854 & 6043.312 & 54 & .000 \\
\hline
\end{tabular}

Table 4. Summary of results for estimating the Multinomial Logistic Regression model on e-Business (information about the model fit)

\begin{tabular}{|l|r|}
\hline Cox y Snell & .453 \\
\hline Nagelkerke & .493 \\
\hline McFadden & .240 \\
\hline
\end{tabular}

Table 5. Pseudo R- squared of model on e-Business

\begin{tabular}{|c|c|c|c|c|}
\hline \multirow[b]{2}{*}{ Effect } & \multirow{2}{*}{$\begin{array}{c}\text { Criteria of model fit } \\
-2 \log \text {-likelihood simplified model }\end{array}$} & \multicolumn{3}{|c|}{ Likelihood ratio test } \\
\hline & & Chi-squared & gl & Sig. \\
\hline Intersection & 18823.854 & .000 & 0 & \\
\hline ZSIZE & 19372.531 & 548.677 & 3 & .000 \\
\hline MANSUPP & 18843.360 & 19.506 & 6 & .003 \\
\hline EXPECTEARN & 18895.305 & 71.451 & 3 & .000 \\
\hline AGE & 18850.256 & 26.402 & 9 & .002 \\
\hline ZHUMANCAP & 18978.178 & 154.324 & 3 & .000 \\
\hline PROYECTINT & 19003.925 & 180.070 & 6 & .000 \\
\hline ZCAPATEC & 19918.350 & 1094.496 & 3 & .000 \\
\hline HUMANCAPICT & 19179.751 & 355.897 & 6 & .000 \\
\hline PARTNERUSE & 18878.681 & 54.827 & 3 & .000 \\
\hline RIVALCOMP & 18836.845 & 12.991 & 3 & .005 \\
\hline COMPARTNERSDISP & 18921.049 & 97.195 & 3 & .000 \\
\hline SECTOR & 18937.047 & 113.193 & 6 & .000 \\
\hline
\end{tabular}

Table 6. Likelihood ratio test of model on e-Business

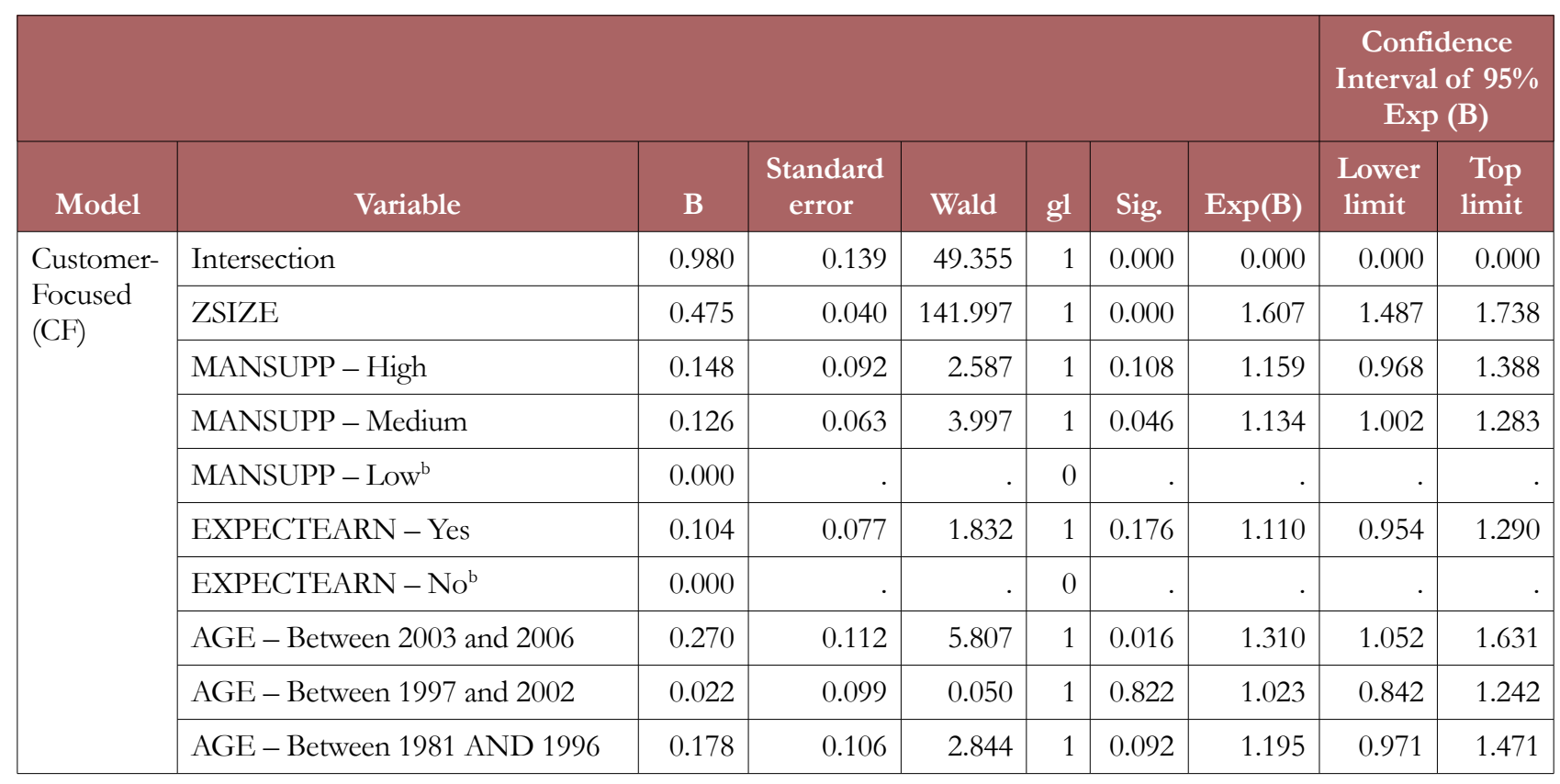




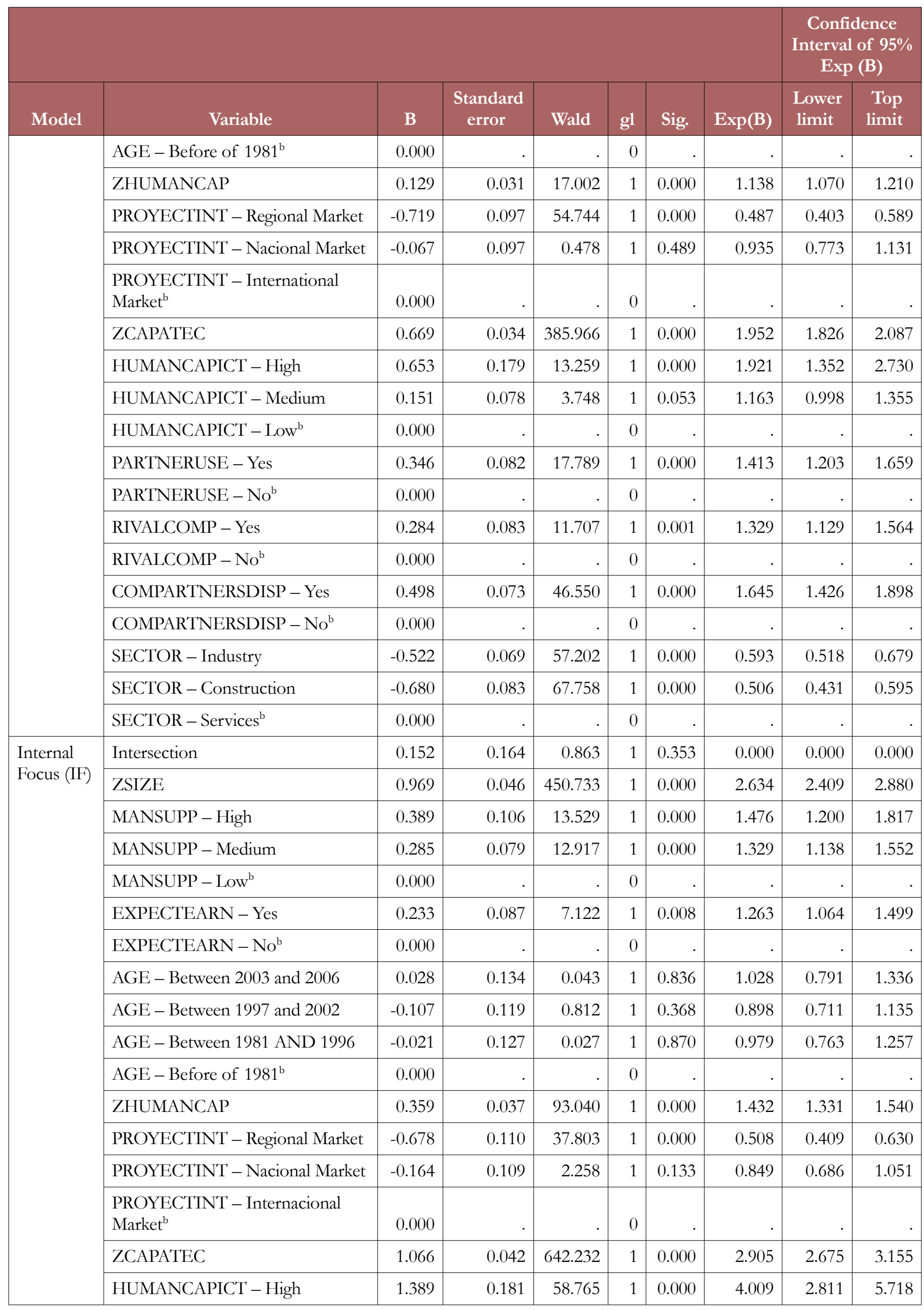




\begin{tabular}{|c|c|c|c|c|c|c|c|c|c|}
\hline \multirow[b]{2}{*}{ Model } & \multirow[b]{2}{*}{ Variable } & \multirow[b]{2}{*}{ B } & \multirow[b]{2}{*}{$\begin{array}{l}\text { Standard } \\
\text { error }\end{array}$} & \multirow[b]{2}{*}{ Wald } & \multirow[b]{2}{*}{ g1 } & \multirow[b]{2}{*}{ Sig. } & \multirow[b]{2}{*}{$\operatorname{Exp}(B)$} & \multicolumn{2}{|c|}{$\begin{array}{c}\text { Confidence } \\
\text { Interval of } 95 \% \\
\text { Exp (B) }\end{array}$} \\
\hline & & & & & & & & $\begin{array}{l}\text { Lower } \\
\text { limit }\end{array}$ & $\begin{array}{l}\text { Top } \\
\text { limit }\end{array}$ \\
\hline & HUMANCAPICT - Medium & 0.526 & 0.086 & 37.759 & 1 & 0.000 & 1.692 & 1.431 & 2.001 \\
\hline & HUMANCAPICT - Low & 0.000 & . & . & 0 & . & . & . & . \\
\hline & PARTNERUSE - Yes & 0.298 & 0.091 & 10.826 & 1 & 0.001 & 1.348 & 1.128 & 1.610 \\
\hline & PARTNERUSE - No ${ }^{b}$ & 0.000 & . & . & 0 & . & . & . & . \\
\hline & RIVALCOMP - Yes & 0.229 & 0.093 & 6.017 & 1 & 0.014 & 1.257 & 1.047 & 1.509 \\
\hline & RIVALCOMP - No ${ }^{b}$ & 0.000 & . & . & 0 & . & . & . & . \\
\hline & COMPARTNERSDISP - Yes & 0.662 & 0.084 & 61.728 & 1 & 0.000 & 1.939 & 1.644 & 2.288 \\
\hline & COMPARTNERSDISP - No ${ }^{b}$ & 0.000 & . & . & 0 & . & . & . & . \\
\hline & SECTOR - Industry & -0.455 & 0.081 & 31.573 & 1 & 0.000 & 0.634 & 0.541 & 0.743 \\
\hline & SECTOR - Construction & -0.708 & 0.098 & 51.686 & 1 & 0.000 & 0.493 & 0.406 & 0.598 \\
\hline & SECTOR - Services ${ }^{\mathrm{b}}$ & 0.000 & . & . & 0 & . & . & . & . \\
\hline \multirow{25}{*}{$\begin{array}{l}\text { First } \\
\text { Movers }\end{array}$} & Intersection & -4.316 & 0.320 & 181.613 & 1 & 0.000 & 0.000 & 0.000 & 0.000 \\
\hline & ZSIZE & 1.088 & 0.067 & 266.273 & 1 & 0.000 & 2.968 & 2.604 & 3.382 \\
\hline & MANSUPP - High & 0.231 & 0.177 & 1.711 & 1 & 0.191 & 1.260 & 0.891 & 1.780 \\
\hline & MANSUPP - Medium & 0.093 & 0.158 & 0.349 & 1 & 0.555 & 1.098 & 0.805 & 1.496 \\
\hline & MANSUPP - Low ${ }^{b}$ & 0.000 & . & . & 0 & . & . & . & . \\
\hline & EXPECTEARN - Yes & 1.139 & 0.145 & 62.081 & 1 & 0.000 & 3.122 & 2.352 & 4.145 \\
\hline & EXPECTEARN - Nob & 0.000 & . & . & 0 & . & . & . & . \\
\hline & AGE - Between 2003 and 2006 & 0.052 & 0.226 & 0.052 & 1 & 0.819 & 1.053 & 0.676 & 1.641 \\
\hline & AGE - Between 1997 and 2002 & -0.327 & 0.206 & 2.519 & 1 & 0.112 & 0.721 & 0.481 & 1.080 \\
\hline & AGE - Between 1981 AND 1996 & 0.159 & 0.211 & 0.571 & 1 & 0.450 & 1.173 & 0.776 & 1.772 \\
\hline & AGE - Before of $1981^{b}$ & 0.000 & . & . & 0 & . & . & . & . \\
\hline & ZHUMANCAP & 0.643 & 0.060 & 113.424 & 1 & 0.000 & 1.902 & 1.690 & 2.141 \\
\hline & PROYECTINT - Regional Market & -1.455 & 0.171 & 72.239 & 1 & 0.000 & 0.233 & 0.167 & 0.326 \\
\hline & PROYECTINT - Nacional Market & -0.173 & 0.151 & 1.318 & 1 & 0.251 & 0.841 & 0.625 & 1.131 \\
\hline & $\begin{array}{l}\text { PROYECTINT - Internacional } \\
\text { Market }^{\text {b }}\end{array}$ & 0.000 & . & . & 0 & . & . & . & . \\
\hline & ZCAPATEC & 2.447 & 0.113 & 472.352 & 1 & 0.000 & 11.552 & 9.265 & 14.404 \\
\hline & HUMANCAPICT - High & 3.102 & 0.227 & 187.191 & 1 & 0.000 & 22.238 & 14.260 & 34.679 \\
\hline & HUMANCAPICT - Medium & 1.753 & 0.161 & 118.642 & 1 & 0.000 & 5.769 & 4.209 & 7.908 \\
\hline & HUMANCAPICT - Low & 0.000 & . & . & 0 & . & . & . & . \\
\hline & PARTNERUSE - Yes & 0.889 & 0.125 & 50.406 & 1 & 0.000 & 2.432 & 1.903 & 3.108 \\
\hline & PARTNERUSE - Nob & 0.000 & . & . & 0 & . & . & . & . \\
\hline & RIVALCOMP - Yes & 0.122 & 0.133 & 0.836 & 1 & 0.361 & 1.130 & 0.870 & 1.467 \\
\hline & RIVALCOMP - No ${ }^{b}$ & 0.000 & . & . & 0 & . & . & . & . \\
\hline & COMPARTNERSDISP - Yes & 1.304 & 0.154 & 71.977 & 1 & 0.000 & 3.685 & 2.726 & 4.980 \\
\hline & COMPARTNERSDISP - No ${ }^{b}$ & 0.000 & . & . & 0 & . & . & . & . \\
\hline
\end{tabular}




\begin{tabular}{|c|c|c|c|c|c|c|c|c|c|}
\hline \multirow[b]{2}{*}{ Model } & \multirow[b]{2}{*}{ Variable } & \multirow[b]{2}{*}{ B } & \multirow[b]{2}{*}{$\begin{array}{l}\text { Standard } \\
\text { error }\end{array}$} & \multirow[b]{2}{*}{ Wald } & \multirow[b]{2}{*}{ gl } & \multirow[b]{2}{*}{ Sig. } & \multirow[b]{2}{*}{$\operatorname{Exp}(B)$} & \multicolumn{2}{|c|}{$\begin{array}{c}\text { Confidence } \\
\text { Interval of } 95 \% \\
\text { Exp (B) }\end{array}$} \\
\hline & & & & & & & & $\begin{array}{l}\text { Lower } \\
\text { limit }\end{array}$ & $\begin{array}{l}\text { Top } \\
\text { limit }\end{array}$ \\
\hline & SECTOR - Industry & -0.851 & 0.126 & 45.664 & 1 & 0.000 & 0.427 & 0.334 & 0.547 \\
\hline & SECTOR - Construction & -1.350 & 0.195 & 47.747 & 1 & 0.000 & 0.259 & 0.177 & 0.380 \\
\hline & SECTOR - Services $^{b}$ & 0.000 & . & . & 0 & . & . & . & . \\
\hline
\end{tabular}

b: This parameter is set to zero because it is redundant.

Table 7. Parameter estimates of model on e-business (Late Movers as reference category)

\begin{tabular}{|l|r|r|r|r|r|}
\hline & Predicted & & & \\
\hline Observed & Late movers & Customer Focus & Internal Focus & First Movers & Correct percentage \\
\hline Late movers & 1778 & 857 & 55 & 1 & 66.07 \\
\hline Customer Focus & 749 & 2438 & 685 & 39 & 62.34 \\
\hline Internal Focus & 138 & 832 & 1652 & 98 & 60.74 \\
\hline First Movers & 0 & 31 & 226 & 430 & 62.59 \\
\hline Global percentage & 26.63 & 41.54 & 26.16 & 5.67 & 62.92 \\
\hline
\end{tabular}

Table 8. Classification table of model on e-Business

As mentioned above, this table takes as its reference the category of Late Movers. This implies that the coefficients are established in order to determine how the different variables moderate the probability that a certain firm is in one category as compared to the probability of it being in the category of Late Movers. Beginning with the variables linked to the firm, size (ZSIZE) in the first of the models clearly has a positive and statistically significant effect, which makes it more likely that the enterprise will be placed in the categories of CF, IF, and First Movers. Among these categories, nevertheless, there are very significant differences between the CF category and the others. It is noticeable that the variable's coefficient, while still positive, is substantially lower in this category than in the other two. Nevertheless, the difference between the categories of IF and First Movers, although present and favourable to the latter, is smaller. These conclusions are consistent with those established in the partial analysis although, as is to be expected, the effect is smaller. Based on these considerations, the hypothesis proposed in the theoretical model cannot be refuted.

The variable of management support (MANSUPP) is weak in terms of statistical performance. In general, the model's coefficients are not significant, which means that the sign and intensity of the effect shown should be taken with great caution. Nevertheless, in the light of the individual tests performed with this variable regarding the level of e-business adoption, it may be affirmed that the greater the amount of management support, the greater the probability of being in categories that reflect a greater adoption of these technological capabilities.

Regarding the outlook for earnings (EXPECTEARN), the table reveals a significant and positive relationship between the presence of these expectations and the greater probability that the firm will belong to a category other than Late Movers. As can be seen in the CF model of firms, the effect of having such expectations increases the likelihood of being in this category rather than in the category of Late Movers. Nonetheless, this effect is not statistically significant. The influence in the case of the IF category takes exactly the same direction, although in this case it is significant at 99\%, and the effect's intensity is greater, with it being less likely that firms will belong to the IF category from the perspective of e-business if there are no expectations of earnings. Finally, for the case of First Movers, this same effect is much more pronounced, with a gradient that largely exceeds the coefficients estimated in the previous models, with a significance of $99 \%$. This means that we cannot refute the hypothesis proposed regarding the positive relationship between the existence of expectations of earnings derived from ICTs and a firm's level of adoption of e-business. 
Firm age (AGE) is a variable with limited statistical significance in the model, and whose effect is not very conclusive. In the model's joint analysis, that is, including all the independent variables considered, the effect of the likelihood of being in the CF compared to the group of Late Movers is only significant at 95\%. Specifically, there is a positive effect on the probability of being in the CF group compared to the group of Late Movers for those firms incorporated between 2003 and 2006, that is, the youngest ones among those considered. There is a significant effect at 90\% significance in the same direction as for those firms incorporated between 1981 and 1996. The low statistical significance and the fairly inconclusive results, together with those recorded in the partial models, lead us to reject the hypothesis proposed.

As regards the human capital variable (ZHUMANCAP), measured according to the number of employees with a university qualification, a significant effect at $99 \%$ is observed in the three models described in the table. The first noticeable finding is the probability of being in the CF category rather than in the Late Movers category in step with the higher proportion of employees with a degree. In this same direction, it is noted how the effect is also significant on the probability of being in the IF category compared to the low category and, furthermore, this effect is greater for this second model (the estimated coefficient is 0.359 compared to 0.129 in the previous model). The likelihood of belonging to the First Movers group compared to the Late Movers also increases in step with increases in the level of the firm's human capital, with the effect this time being greater than in the previous cases (with a gradient in the estimated logit of 0.643 ). Therefore, assuming that the CF and IF categories are at an intermediate point, and that First Movers is a clearly superior group in the development of e-business, we cannot reject the hypothesis formulated on the positive effect that human capital has on the level of e-business adoption.

Finally, within the variables linked to the firm, international projection (PROYECTINT) also has statistically significant effects. Generally speaking, the models summarised in the previous table show that there are only significant effects for the regional market category, bearing in mind that the international market is the reference category used in the analysis. Our first conclusion, therefore, is that we may reject the existence of significant differences regarding e-business adoption among firms whose main markets are national compared to those in which their international operations prevail. Nonetheless, this difference does appear to exist in the case of firms focused on their regional market compared to those of an international nature. As is apparent, and once again assuming a relative ordinality in the dependent variable, there seems to be a negative and significant effect (at 99\%) between e-business adoption and the fact that the firm's main market is regional. Moreover, this negative effect is more intense in the case of First Movers (lower probability of being in this category than in the category of Late Movers) than in the other two (IF and CF firms), in which the effect has a very similar intensity. Accordingly, and accepting the symmetrical argument, we cannot refute the hypothesis of a positive and significant relationship between the firm's level of e-business adoption and its degree of international development.

Regarding the second group of variables -those linked to ICTs- the relationships observed in the summary table are noteworthy. Firstly, there is a clear, intense and significant (at 99\%) relationship between the level of availability of ICT infrastructures (ZCAPATEC) and the probability that the firms analysed will be in one or another category of the dependent variable. Thus, regarding the probability of being in the CF category compared to the probability of being a Late Mover in terms of e-business increases in step with a higher level of ICT infrastructures. This effect is amplified in the model referring to IF firms (a gradient of 1.066 compared to 0.669 in the previous case) and it peaks in the case of First Movers (with an estimated coefficient of 2.447). This means we cannot refute the proposed hypothesis on the relationship between the level of ICT infrastructure and the level of e-business adoption.

Along similar lines, the human capital variable linked to ICTs (HUMANCAPICT) also has positive and significant effects (at 99\%) between the firm's degree of development and its level of e-business adoption. Applying the same level of analysis as in the previous case, the probability of being in the CF category compared to being in the group of Late Movers increases in step with the greater development of the human capital linked to ICTs (at a high level of this variable, considered as ordinal, the estimated coefficient is 0.653 , with a significance level of $99 \%$, whereas at a medium level the gradient calculated for the model is 0.151 , with a significance level of $90 \%$ ). It may therefore be noted for this case that there are major differences between the coefficients for one and the other category of 
the independent variable, although in both cases the effect is significant compared to the low development of the human capital linked to ICTs.

This effect is amplified in the consideration of the second model (probability of IF compared to Late Movers), and in this case there are also differences between the categories of the independent variable, with estimated coefficients for the high level and the medium one (compared to the high one) of 1.389 and 0.526 , respectively, both with a significance level of 99\%. Both effect and difference peak in the third model (category of First Movers vs. Late Movers), in which the estimated gradients are 3.102 and 1.753 for the high and low categories of human capital linked to ICTs. We cannot therefore reject the proposed hypothesis, accepting the degree of progression of the level of e-business noted earlier, on the positive relationship between the level of development of the firm's human capital linked to ICTs and its level of e-business adoption.

As regards the variables related to technology, this study has proposed a relationship that appears less in the specialised literature in this field, and which involves the firm's availability of a capability that we have referred to as third-party development (PARTNERUSE) and which, as we have shown, is associated with the firm's skill at entering into stable relationships with strategic suppliers within the scope of ICTs. In this case, all the relationships summarised in the results table regarding the category of Late Movers show that the presence of this capability has positive effects (and significant ones at 99\%) over the probability of being in any one of the alternative categories. Nevertheless, in this case the intensity of the effects records certain peculiarities. Thus, the effect, as in the previous cases, peaks when comparing the category of First Movers with that of Late Movers, with an estimated coefficient of 0.889 for the presence of the aforementioned capability. However, in the case of the IF and CF categories (always with respect to the probability of being in the category of Late Movers) the effect, albeit in the same direction (i.e., positive for the case of the availability of the capability), is slightly higher for CF than for IF (coefficient of 0.346 compared to 0.298). Therefore, although this is not a particularly large difference, it does confirm the doubts that were raised (and which have already been reflected in other independent variables) regarding the precedence between IF and CF in terms of the level of e-business adoption. This does not mean, however, that these results cannot be used to refute the proposed hypothesis on the positive relationship between the availability of capabilities linked to third-party development and the firm's level of e-business adoption.

The last block of explanatory variables considered is linked to the environment in which the firm operates, with two main aspects being proposed: competitor rivalry within the field of e-business and the attitude of trading partners. As regards the first variable (RIVALCOMP), the results are somewhat contradictory. It may be observed that the effect of the presence of such rivalry is always positive for the categories of CF, IF, and First Movers regarding the category of Late Movers; in this sense, the effect's directions are consistent with the predictions made by the proposed theory. Nevertheless, when considering the intensity of the effect it is noted that it is significant at 99\%, peaking in the case CF, and significant (at 95\%) although weaker in the case of IF. The interpretation that can therefore be made is that competition has a greater impact for those firms whose e-business is more market oriented. Finally, the effect in the case of First Movers is positive but not significant. A possible interpretation for this result is that these firms are simply indifferent to their competitors' behaviour, as their commitment to e-business outweighs this influence.

Regarding the attitude of trading partners (COMPARTNERSDISP), results have indeed been forthcoming that enable us to refute the hypothesis formulated, whereby there appears to be a positive relationship between the pro-e-business attitude of such partners and the firm's level of e-business adoption. Thus, in the three models summarised in the table the effect of having such a capability (as opposed to not having it) is positive and significant at $99 \%$, with the effect being more intense in the case of First Movers (compared to Late Movers), medium in the case of IF firms, and lower (although also relevant) in the case of CF firms.

To conclude our analysis of these results, stress should be placed on the existence of significant differences in e-business adoption depending on the industry in which the firm operates -the sole control variable used in the analysis. In general terms, there is a negative effect for firms that are not involved in the services sector, being more intense in the case of construction companies than in industrial firms. 
In the light of these results, many of the questions that the analytical model poses are answered. Nonetheless, it is worth focusing on the study of the relationship between the intermediate groups in which, as we have seen, there are certain fairly inconclusive results. To do so, an identical analysis has been conducted to the one described in the preceding pages, although on this occasion taking the CF category as the reference. The estimations' results are summarised in Table 9.

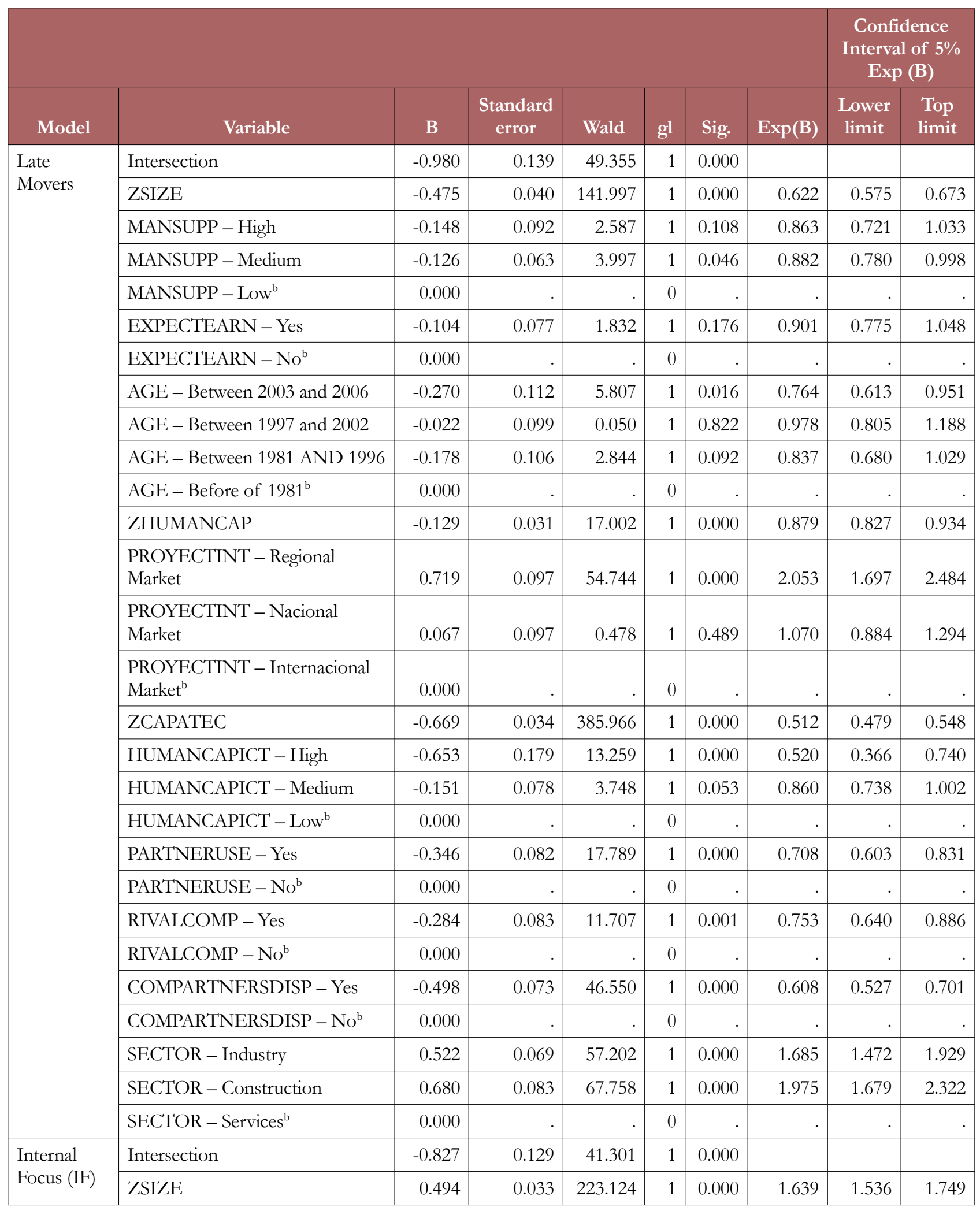




\begin{tabular}{|c|c|c|c|c|c|c|c|c|c|}
\hline \multirow[b]{2}{*}{ Model } & \multirow[b]{2}{*}{ Variable } & \multirow[b]{2}{*}{ B } & \multirow[b]{2}{*}{$\begin{array}{l}\text { Standard } \\
\text { error }\end{array}$} & \multirow[b]{2}{*}{ Wald } & \multirow[b]{2}{*}{ g1 } & \multirow[b]{2}{*}{ Sig: } & \multirow[b]{2}{*}{$\operatorname{Exp}(B)$} & \multicolumn{2}{|c|}{$\begin{array}{l}\text { Confidence } \\
\text { Interval of } 5 \% \\
\operatorname{Exp}(\mathrm{B})\end{array}$} \\
\hline & & & & & & & & $\begin{array}{l}\text { Lower } \\
\text { limit }\end{array}$ & $\begin{array}{l}\text { Top } \\
\text { limit }\end{array}$ \\
\hline & MANSUPP - High & 0.242 & 0.081 & 8.898 & 1 & 0.003 & 1.274 & 1.086 & 1.493 \\
\hline & MANSUPP - Medium & 0.159 & 0.067 & 5.551 & 1 & 0.018 & 1.172 & 1.027 & 1.338 \\
\hline & MANSUPP - Low ${ }^{\mathrm{b}}$ & 0.000 & . & . & 0 & . & . & . & . \\
\hline & EXPECTEARN - Yes & 0.129 & 0.066 & 3.858 & 1 & 0.049 & 1.138 & 1.000 & 1.295 \\
\hline & EXPECTEARN - No & 0.000 & . & . & 0 & . & . & . & · \\
\hline & AGE - Between 2003 and 2006 & -0.242 & 0.109 & 4.933 & 1 & 0.026 & 0.785 & 0.634 & 0.972 \\
\hline & AGE - Between 1997 and 2002 & -0.130 & 0.100 & 1.687 & 1 & 0.194 & 0.878 & 0.722 & 1.068 \\
\hline & AGE - Between 1981 AND 1996 & -0.199 & 0.105 & 3.594 & 1 & 0.058 & 0.819 & 0.667 & 1.007 \\
\hline & AGE - Before of $1981^{b}$ & 0.000 & . & . & 0 & $\cdot$ & . & . & · \\
\hline & ZHUMANCAP & 0.230 & 0.030 & 59.497 & 1 & 0.000 & 1.258 & 1.187 & 1.334 \\
\hline & $\begin{array}{l}\text { PROYECTIN'T - Regional } \\
\text { Market }\end{array}$ & 0.041 & 0.080 & 0.264 & 1 & 0.607 & 1.042 & 0.891 & 1.219 \\
\hline & $\begin{array}{l}\text { PROYECTINT - Nacional } \\
\text { Market }\end{array}$ & -0.096 & 0.075 & 1.654 & 1 & 0.198 & 0.908 & 0.784 & 1.052 \\
\hline & $\begin{array}{l}\text { PROYECTINT - Internacional } \\
\text { Market }^{\text {b }}\end{array}$ & 0.000 & . & . & 0 & . & . & . & . \\
\hline & ZCAPATEC & 0.398 & 0.034 & 135.230 & 1 & 0.000 & 1.488 & 1.392 & 1.591 \\
\hline & HUMANCAPICT - High & 0.736 & 0.089 & 67.761 & 1 & 0.000 & 2.087 & 1.751 & 2.486 \\
\hline & HUMANCAPICT - Medium & 0.375 & 0.063 & 36.037 & 1 & 0.000 & 1.455 & 1.287 & 1.645 \\
\hline & HUMANCAPICT - Low & 0.000 & $\cdot$ & . & 0 & . & $\cdot$ & . & . \\
\hline & PARTNERUSE - Yes & -0.047 & 0.062 & 0.578 & 1 & 0.447 & 0.954 & 0.844 & 1.077 \\
\hline & PARTNERUSE - No ${ }^{\mathrm{b}}$ & 0.000 & $\cdot$ & $\cdot$ & 0 & . & $\cdot$ & . & · \\
\hline & RIVALCOMP - Yes & -0.055 & 0.067 & 0.677 & 1 & 0.411 & 0.946 & 0.829 & 1.079 \\
\hline & RIVALCOMP $-\mathrm{No}^{\mathrm{b}}$ & 0.000 & . & $\cdot$ & 0 & . & . & . & $\cdot$ \\
\hline & COMPARTNERSDISP - Yes & 0.164 & 0.065 & 6.338 & 1 & 0.012 & 1.179 & 1.037 & 1.340 \\
\hline & COMPARTNERSDISP $-\mathrm{No}^{\mathrm{b}}$ & 0.000 & . & . & 0 & . & . & . & . \\
\hline & SECTOR - Industry & 0.066 & 0.062 & 1.145 & 1 & 0.285 & 1.069 & 0.946 & 1.207 \\
\hline & SECTOR - Construction & -0.027 & 0.080 & 0.116 & 1 & 0.734 & 0.973 & 0.833 & 1.137 \\
\hline & SECTOR - Services ${ }^{b}$ & 0.000 & . & . & 0 & . & . & . & . \\
\hline \multirow{9}{*}{$\begin{array}{l}\text { Fisrt } \\
\text { Movers }\end{array}$} & Intersection & -5.295 & 0.300 & 310.944 & 1 & 0.000 & & & \\
\hline & ZSIZE & 0.613 & 0.058 & 112.995 & 1 & 0.000 & 1.847 & 1.649 & 2.068 \\
\hline & MANSUPP - High & 0.083 & 0.160 & 0.271 & 1 & 0.603 & 1.087 & 0.794 & 1.487 \\
\hline & MANSUPP - Medium & -0.032 & 0.150 & 0.046 & 1 & 0.830 & 0.968 & 0.721 & 1.300 \\
\hline & MANSUPP - Low ${ }^{\mathrm{b}}$ & 0.000 & . & . & 0 & . & . & . & $\cdot$ \\
\hline & EXPECTEARN - Yes & 1.035 & 0.130 & 62.865 & 1 & 0.000 & 2.814 & 2.179 & 3.634 \\
\hline & EXPECTEARN - Nob & 0.000 & . & . & 0 & . & . & . & . \\
\hline & AGE - Between 2003 and 2006 & -0.218 & 0.209 & 1.088 & 1 & 0.297 & 0.804 & 0.534 & 1.211 \\
\hline & AGE - Between 1997 and 2002 & -0.349 & 0.192 & 3.306 & 1 & 0.069 & 0.705 & 0.484 & 1.028 \\
\hline
\end{tabular}




\begin{tabular}{|c|c|c|c|c|c|c|c|c|c|}
\hline \multirow[b]{2}{*}{ Model } & \multirow[b]{2}{*}{ Variable } & \multirow[b]{2}{*}{ B } & \multirow[b]{2}{*}{$\begin{array}{l}\text { Standard } \\
\text { error }\end{array}$} & \multirow[b]{2}{*}{ Wald } & \multirow[b]{2}{*}{ g1 } & \multirow[b]{2}{*}{ Sig. } & \multirow[b]{2}{*}{$\operatorname{Exp}(B)$} & \multicolumn{2}{|c|}{$\begin{array}{l}\text { Confidence } \\
\text { Interval of 5\% } \\
\text { Exp (B) }\end{array}$} \\
\hline & & & & & & & & $\begin{array}{l}\text { Lower } \\
\text { limit }\end{array}$ & $\begin{array}{l}\text { Top } \\
\text { limit }\end{array}$ \\
\hline & AGE - Between 1981 AND 1996 & -0.019 & 0.194 & 0.010 & 1 & 0.921 & 0.981 & 0.670 & 1.436 \\
\hline & AGE - Before of $1981^{b}$ & 0.000 & & . & 0 & & & . & . \\
\hline & ZHUMANCAP & 0.514 & 0.055 & 87.004 & 1 & 0.000 & 1.672 & 1.501 & 1.862 \\
\hline & $\begin{array}{l}\text { PROYECTINT - Regional } \\
\text { Market }\end{array}$ & -0.736 & 0.151 & 23.772 & 1 & 0.000 & 0.479 & 0.356 & 0.644 \\
\hline & $\begin{array}{l}\text { PROYECTINT - Nacional } \\
\text { Market }\end{array}$ & -0.106 & 0.126 & 0.709 & 1 & 0.400 & 0.899 & 0.702 & 1.151 \\
\hline & $\begin{array}{l}\text { PROYECTINT - Internacional } \\
\text { Market }^{\text {b }}\end{array}$ & 0.000 & & . & 0 & & & . & \\
\hline & ZCAPATEC & 1.778 & 0.109 & 265.545 & 1 & 0.000 & 5.918 & 4.779 & 7.329 \\
\hline & HUMANCAPICT - High & 2.449 & 0.159 & 236.513 & 1 & 0.000 & 11.574 & 8.471 & 15.814 \\
\hline & HUMANCAPICT - Medium & 1.602 & 0.148 & 117.574 & 1 & 0.000 & 4.961 & 3.714 & 6.627 \\
\hline & HUMANCAPICT - Low & 0.000 & $\cdot$ & . & 0 & & & $\cdot$ & \\
\hline & PARTNERUSE - Yes & 0.543 & 0.104 & 27.261 & 1 & 0.000 & 1.721 & 1.404 & 2.110 \\
\hline & PARTNERUSE - No ${ }^{b}$ & 0.000 & $\cdot$ & . & 0 & & & $\cdot$ & \\
\hline & RIVALCOMP - Yes & -0.162 & 0.114 & 2.031 & 1 & 0.154 & 0.850 & 0.680 & 1.063 \\
\hline & RIVALCOMP - Nob & 0.000 & $\cdot$ & . & 0 & & & $\cdot$ & · \\
\hline & COMPARTNERSDISP - Yes & 0.806 & 0.142 & 32.076 & 1 & 0.000 & 2.239 & 1.694 & 2.960 \\
\hline & COMPARTNERSDISP $-\mathrm{No}^{\mathrm{b}}$ & 0.000 & & . & 0 & & & $\cdot$ & . \\
\hline & SECTOR - Industry & -0.329 & 0.112 & 8.563 & 1 & 0.003 & 0.720 & 0.577 & 0.897 \\
\hline & SECTOR - Construction & -0.670 & 0.184 & 13.191 & 1 & 0.000 & 0.512 & 0.357 & 735 \\
\hline & SECTOR - Services ${ }^{\mathrm{b}}$ & 0.000 & . & . & 0 & & & . & \\
\hline
\end{tabular}

a: The reference category is Customer Focus (CF).

b: This parameter is set to zero because it is redundant.

Table 9. Summary of results for estimating the Multinomial Logistic Regression model on e-Business ${ }^{\text {a }}$

Considering the model that relates two categories of relevance to the analysis conducted, there are three interesting conclusions to be drawn. Focusing firstly on the variables linked to the firm, size has a positive and significant effect, albeit of limited intensity, on the probability that a firm will be classified as IF compared to the probability it will feature in the CF group. The variable MANSUPP also has a positive and significant effect in this same model, although it is once again noted that the effect's intensity, measured from the estimated gradient, seems limited in comparison to previous models and the effect that may be observed regarding the other categories included in the analysis. This same situation applies to the variable ZHUMANCAP, which also records a significant and positive effect, albeit of low intensity.

Special note should be taken, however, of the loss of significance of the variable EXPECTEARN, which indicates a positive and significant effect at 95\%, also of a very slight nature, and the absence of significance of the variable PROYECTINT, which means there are no statistically significant differences regarding the effect generated by the size of the firm's reference market in relation to the probability of being in the IF category as opposed to the CF one. 
Insofar as the technology variables, in general, are concerned, it is noted that the conclusions drawn from the first model are upheld, inasmuch as the results reveal a positive and significant relationship of the variables ZCAPATEC and HUMANCAPICT. Nevertheless, once again the variable PARTNERUSE does not appear to have any significant effects on the likelihood ratio of being in the IF category compared to the CF one.

As regards the variables linked to the environment, the table reveals the non-significance of the variable RIVALCOMP and the presence of a slight but significant relationship between COMPARTNERSDISP and the aforementioned likelihood ratio.

A joint analysis of these results lends support to the conclusions on the fuzzy line that separates these two groups. Nevertheless, the existence of multiple significant relationships and the favourable sign in all cases of the IF category seem to suggest there is a certain order between the two categories, favouring, as proposed, those firms with a greater internal focus.

In short, Table 10 recaps the conclusions drawn from the analysis of the regression models in relation to the hypotheses formulated by García-Moreno et al. (2016).

According to these premises, note should be taken of the first contribution made in this section, namely, the holistic vocation of the approach made, being encapsulated in two aspects. On the one hand, that ambitious nature has been realised in the actual development of this work's core purpose: measuring the level of e-business adoption. The difficulties associated with the conceptualisation itself, which have given rise to a certain methodological confusion, together with the absence of specific data on business practices within this ambit, have meant that most of the studies reviewed have, from our standpoint, underspecified the metrics of e-business, circumscribing the concept to partial aspects that have mostly focused on the part linked to e-commerce.

This aspect, of undoubted interest from a scholarly perspective and from a business point of view, is no more than part of a larger whole that, according to the definition provided here, should consider other aspects: the use of technologies such as the intranet, knowledge management software, integrated management applications, and customer relationship management, as facets that more fully and accurately define the concept studied.

Informed by this reasoning, an effort has been made to propose both a clear and comprehensive concept of e-business and a methodological alternative based on cluster analysis to identify different business profiles within this ambit. We consider both aspects to be valuable because they may provide the launch pad for future research.

\begin{tabular}{|c|c|c|c|}
\hline & Hypothesis - Variable & Relation & Contrast Result \\
\hline \multirow{6}{*}{ FIRM } & H1: Size & Positive & $\sqrt{ }$ \\
\hline & H2: Management's support & Positive & $\sqrt{ }$ \\
\hline & H3: Profit expectations & Positive & $\sqrt{ }$ \\
\hline & H4: Size & Negative & $\mathrm{x}$ \\
\hline & H5: Human capital & Positive & $\sqrt{ }$ \\
\hline & H6: International projection & Positive & $\sqrt{ }$ \\
\hline \multirow{3}{*}{ TECHNOLOGY } & H7: Technological infraestructura & Positive & $\sqrt{ }$ \\
\hline & H8: Human capital ICT & Positive & $\sqrt{ }$ \\
\hline & H9: Third-party development & Positive & $\sqrt{ }$ \\
\hline \multirow{2}{*}{ ENVIRONMENT } & H10: Competitor rivalry & Positive & ¿? \\
\hline & H11: Attitude of trading partners & Positive & $\sqrt{ }$ \\
\hline
\end{tabular}

Table 10. Summary of results for the estimation of multinomial logistic regression model 
This research is original in several ways. It validates a model propounded by the authors García Moreno et al. (2016), based on the non-existence of prior models that seek to verify such a large number of hypotheses. The reason for including such a high number of variables is to obtain a model with a greater explanatory capability. The aim is therefore to single out the true effects that the factors considered have on e-business adoption, simultaneously considering all the variables in their entirety.

In terms of methodology, we should not forget to mention the work, not without its difficulties, involving a database of the size used here, with over 14,000 enterprises from all over Europe. This sample provides major support for the possible extrapolation of the results provided by the empirical study and, once again, implies a certain degree of originality inasmuch as the literature does not contain any studies with such a broad perspective as the one considered here.

As regards the results of the relationship model considered involving multinomial logistic regression, specific mention should first be made of the broad fulfilment of the sum of hypotheses proposed by García Moreno et al. (2016), which confirms the explanatory validity of the variables considered. Following the order established throughout this work, we can see that the sum of variables linked to the firm go a very long way to explaining e-business adoption.

As noted in the theoretical development, firm size appears to be directly linked to the level of e-business adoption by enterprises, or at least, the statistical verifications made have not permitted us to refute the hypothesis on the existence of such a relationship. Quite the contrary, the results show that larger firms are also the ones that in a greater proportion feature among the profiles identified as the most advanced in the field of e-business. It is obviously reasonable to assume that the influence of firm size has a relational component with other independent variables that, nevertheless, the multicollinearity tests seem to highlight in the sample used. In any case, the results do not allow negating the relationship considered.

Also, of significance is the relationship between the level of a firm's human capital and the level of e-business adoption: the higher the level of a firm's human capital, the more likely the firm is to record higher levels of e-business adoption. This means the hypothesis in question cannot be rejected. In this case, the effect appears to be more moderate than in the case of firm size, which also stands to reason considering that the launch of e-business in firms of a certain size may be seen as a strategic condition, whereas a high level of human capital in the enterprise does not necessarily imply this requirement, but instead may act as a driving force, although not essentially an obligation for competing.

Neither have we been able to validate the influences that a firm's expectations for earnings from ICTs have on the level of e-business adoption. With certain nuances, there once again appear to be a number of similarities between firms that have greater expectations and those that record higher levels of e-business adoption. In other words, firms are rational agents, and so the assumption that a resource or capability is valuable, in this case e-business practices, reflects a desire to achieve that resource or capability.

Likewise, and based on the results obtained, a firm's international projection, more specifically the scope of its operations, seems to maintain some relationship with the adoption of practices linked to e-business. Specifically, the results reveal a clear effect in the opposite direction: firms with a regional operating ambit are less likely to record higher levels of e-business adoption. Nevertheless, firms whose main market is national in scope do not differ significantly from enterprises whose target audience is the international market. In other words, the fault-line in this variable as regards e-business adoption lies between the regional and national market, rather than between the national and international ones. Thus, the relationship that cannot be rejected on the basis of the results obtained is that there is a market size as of which there is a greater propensity among firms to adopt practices linked to e-business adoption.

The other two variables considered within the group of those linked to the firm have more contradictory results, albeit requiring certain clarifications. On the one hand, the variable of management support for technology has a relationship in management that the theory predicts; that is, the greater this support, the greater the probability of recording a high level of adoption. Nevertheless, whereas the effect is clearly seen in the individual model, its inclusion in the joint model dilutes this effect. The explanation for this phenomenon is undoubtedly to be found in 
the existence of indirect relationships with other independent variables insofar as it seems logical to assume that higher levels of management support will also be reflected in more complete technological infrastructures, higher levels of human capital linked to ICTs, and the development of capabilities linked to technology, such as third-part development. This circumstance conditions the analysis, and although the results may prompt a rejection of the hypothesis, this possible interrelationship recommends a more cautious interpretation.

On the other hand, the age variable behaves in a truly erratic, random and contradictory manner. Given the scant probability of measurement issues or the contradictory effects of the general and individual models, the results are an invitation to refute the existence of a direct relationship between firm age and the level of e-business adoption. This circumstance does not fully rule out the existence of relationships, but it does indicate that these links are probably more complex than those considered in the analytical model. It may therefore be the case that the interaction with other variables could shed some light on the role this variable plays in explaining a firm's level of e-business. Nevertheless, this approach is part of the future lines of research that will be proposed as an extension of this study.

To conclude, it cannot be refuted that the factors related to the firm, which have been considered in the analytical model, are closely associated with the level of e-business adoption, confirming the importance these characteristics have in the study of this variable. On the other hand, it is worth reminding ourselves of the reasoning put forward by the Resource-Based View on the creation of capabilities and the relationship between them. Thus, the major presence of resources and capabilities that complement ICTs appears to be faithfully reflected in these conclusions: aspects such as human capital or management support seem to act as leverages that, together with other resources, may help to explain the creation of other capabilities, in this case linked to e-business.

Along these lines and staying with the factors related to the use of ICTs within a firm, the three variables included in this ambit have recorded statistically significant relationships in the model considered, suggesting that the hypotheses formulated should not be rejected. The intensity of the relationships, however, differs. Thus, the ICT infrastructure, given the important weight that its coefficients have in the regression, stands as a determining factor, pointing to the resource's co-specialised nature (Powell \& Dent-Micallef, 1997) as regards a firm's e-business capability. This role is also present in terms of the human capital linked to ICTs, revealing what is probably a combination between boosting and requiring technical knowledge among the firm's human resources in order to provide a higher level of adoption of e-business practices.

Albeit with a more moderate effect, the ability to enter into relationships with third parties within the ambit of ICTs also has a relevant role to play in the model, with significant effects that gain in strength as they are tested in models that seek to explain the probability of recording higher levels of e-business adoption. Nevertheless, from a theoretical perspective, and considering the intensity of the effect in this case, the data appear to suggest that this capability plays more of a complementary role than one of co-specialisation.

Finally, the variables related to the environment that have been included in the model also record statistically significant relationships in the direction the theory suggests, which means we cannot refute the hypotheses considered, albeit with nuances that have already been highlighted in the analysis of results. Thus, the attitude of trading partners (customers and suppliers) seems to have a relevant and growing impact on the dependent variable, which is reflected in a higher probability in the models that deal with the likelihood that firms will feature in more advanced categories. Nevertheless, the effect of competitor rivalry has a more erratic influence that is encapsulated in a significant relationship in the intermediate models, with a greater probability of featuring in the category of customer-focused firms, and less so in that of firms with an internal focus.

To end, Figure 2 replicates the full research model propounded by García Moreno et al. (2016), showing the results obtained for the hypotheses considered: 


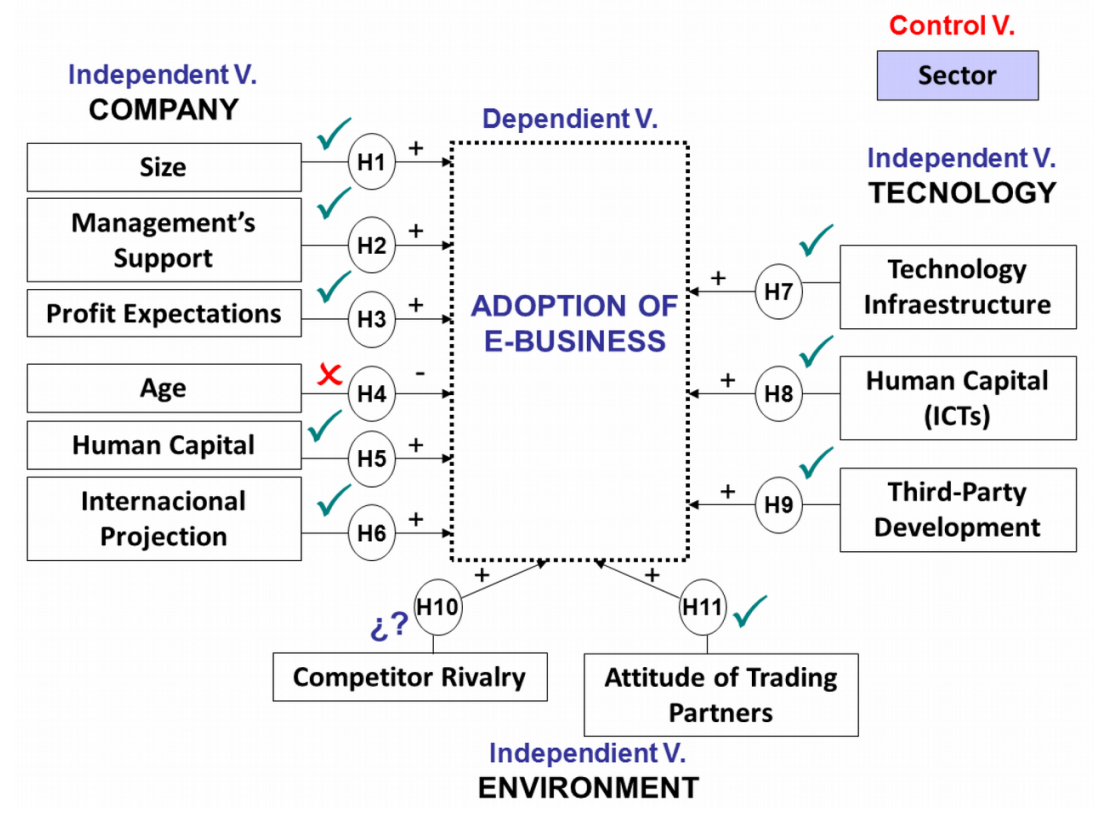

Figure 2. Hypothesis testing

\section{Discussion and Conclusions}

This study validates the theoretical model developed by García Moreno et al. (2016) that sheds light on the potential relationship between the adoption of e-business tools and any organisational, technological and environmental aspects that may be related. Although prior research provides evidence on the adoption of e-business, there is not a single pan-European study in the literature.

As it has been shown in results, amongst the organizational factors, firm's size impacts in e-business adoption as it was proposed in the model. Precedent analyses have confirmed this same orientation (Kowtha \& Choon, 2001; Bertschek \& Fryges, 2002; Zhu et al., 2003, 2006; Bayo-Moriones \& Lera-López, 2007; Vladimirov, 2015, Chatzoglou \& Chatzoudes, 2016). Same way, management's support also shows positive impacts, similar to the ones described in the researches done by Soliman and Janz (2004), Ifinedo (2011) and Vladimirov (2015).

In relation to expectations on returns from e-business adoption, results from this research are aligned with proposals coming from Beatty et al. (2001), Chwelos et al. (2001), Grandon and Pearson (2004), Hsu, Kraemer and Dunkle (2006), Lin and Lin (2008), Wang and Ahmed (2008), Bordonaba-Juste, Lucia-Palacios and Polo-Redondo (2012), Padrón-Cantú, Molina-Morejón and Méndez-Wong (2014) and Vladimirov (2015). All of them show a positive impact of these expectations too.

Firm's age also shows a similar behavior as previous studies in which not enough evidence has been found in the literature. Concretely, our analysis has not found statistically significant relationships at all, while Bertschek and Fryges (2002) found weak relationships. Awa, Ojiabo and Emecheta (2015) affirm the existence of this relationship although it does not apply for the case of small size firms and related only to ICT instead to e-business. No previous references showing positive relationships have been found for a sample including firms of all sizes.

Dealing with the positive impact of human capital in e-business adoption, the results are aligned with previous literature (Bertschek \& Fryges, 2002; Zhu et al., 2006; Bayo-Moriones \& Lera-López, 2007). Similarly, international projection is positively associated to higher levels of e-business adoption, as reported by Bertschek and Fryges (2002), Zhu et al. (2006) and Abebe (2014).

Regarding technological factors, the proposed hypotheses have not been validated as observed in the results' part. This way, related to technological infrastructure, results agree with Lin and Lin (2008) research, Camisón and Villar-López (2014) and Chatzoglou and Chatzoudes (2016) in which the availability of these resources position firms in a better situation for e-business adoption. Similarly, human capital linked to ICTs appears as a required 
complement for e-business adoption, as a positive relationship amongst these resources and this adoption is evidenced. Molla \& Licker (2005), Lin \& Lin (2008), Alpkan, Bulut Gunday, Ulusoy and Kilic (2010), Bordonaba-Juste et al. (2012), Stam, Arzlanian and Elfring (2014), Greene, Brush and Brown (2015) and Chatzoglou and Chatzoudes (2016) present similar results. Finally, for the case of Development to Third Parties, the available empirical literature is very scarce. Previous concluding results regarding this relationship have not been found.

In the part of factors related with the environment, the analysis of attitudes with commercial stakeholders show a positive impact on e-business adoption for the sample of the analyzed firms. These results agree with Zhu et al. (2003), Ranganathan et al. (2004), Soliman and Janz (2004) and Wang and Ahmed (2008) and differ from Ifinedo (2011). In respect to the competitor's rivalry, results are inconclusive. From this perspective, this research differs from conclusions presented by Soliman and Janz (2004), Grandon and Pearson (2004), Zhu et al. (2006), Lin and Lin (2008), Wang and Ahmed (2008), Ifinedo (2011) and Saboniene (2015) that show a positive relationship.

This study describes the metrics for the level of e-business adoption, proposing four categories of firms: First Movers, those with an Internal Focus, those with a Customer Focus, and Late Movers, providing a single measure that overcomes the issues arising with ordinal measures or classifications, where the author subjectively gives greater weight or more importance to certain technologies over others, leading to a less efficient classification.

On the other hand, and from a more professional or corporate perspective, this study reveals the importance of variables that a firm can control, such as the role that management support plays when adopting a new technology, and more specifically, e-business. Top management should be mindful of this, and give technology the importance it deserves, investing in it, and creating a stock of human capital that can meet the requirements that its use entails, as this will increase the adoption of the e-business tools that are so important to their firm.

Declaration of Conflicting Interests

The authors declared no potential conflicts of interest with respect to the research, authorship, and/or publication of this article.

\section{Declaration of Conflicting Interests}

The authors declared no potential conflicts of interest with respect to the research, authorship, and/or publication of this article.

\section{Funding}

This paper has been supported by Project ECO2015-67434-R (MINECO/FEDER) of Spanish Ministry of Economy and Competitiveness (Spain) and for the Excellent Research Group "Strategor" of URJC-Bank of Santander.

\section{References}

Abebe, M. (2014). Electronic commerce adoption, entrepreneurial orientation and small-and mediumsized enterprise (SME) performance. Journal of Small Business and Enterprise Development, 21(1), 100-116. https://doi.org/10.1108/JSBED-10-2013-0145

Alpkan, L., Bulut, C., Gunday, G., Ulusoy, G., \& Kilic, K. (2010). Organizational support for intrapreneurship and its interaction with human capital to enhance innovative performance. Management Decision, 48(5), 732-755. https://doi.org/10.1108/00251741011043902

Antonelli, C. (2014). The economics of innovation, new technologies and structural change. New York: Routledge.

Arnett, K., \& Jones, M. (1994). Firms that choose outsourcing: A profile. Information \& Management, 26, $179-188$. https://doi.org/10.1016/0378-7206(94)90091-4

Awa, H.O., Ojiabo, O.U., \& Emecheta, B.C. (2015). Integrating TAM, TPB and TOE frameworks and expanding their characteristic constructs for e-commerce adoption by SMEs. Journal of Science \& Technology Policy Management, 6(1), 76-94. http://dx.doi.org/10.1108/JSTPM-04-2014-0012 
Bayo-Moriones, A., \& Lera-Lopez, F. (2007). A firm-level analysis of determinants of ICT adoption in Spain. Technovation, 27, (6-7), 352-366. https://doi.org/10.1016/j.technovation.2007.01.003

Beatty, R.C. Shim, J.P., \& Jones, C.J. (2001). Factors influencing corporate web site adoption: A time-based assessment. Information \& Management, 38, 337-354. https://doi.org/10.1016/S0378-7206(00)00064-1

Bertschek, I., \& Fryges, H. (2002). The adoption of B2B e-commerce: Empirical evidence for german companies. ZEW Discussion Paper, 02-05, Mannheim, Germany.

Bloom, N., Propper, C., Seiler, S., \& Van Reenen, J. (2015). The impact of competition on management quality: evidence from public hospitals. The Review of Economic Studies, 82(2), 457-489. https://doi.org/10.1093/restud/rdu045

Bordonaba-Juste, V., Lucia-Palacios, L., Polo-Redondo, Y. (2012). Antecedents and consequences of e-business adoption for European retailers. Internet Research, 22(5), 532-550. https://doi.org/10.1108/10662241211271536

Buabeng-Andoh, C. (2012). Factors influencing teachers' adoption and integration of information and communication technology into teaching: A review of the literature. International Journal of Education and Development using Information and Communication Technology, 8 (1), 136-155.

Camisón, C., \& Villar-López, A. (2014). Organizational innovation as an enabler of technological innovation capabilities and firm performance. Journal of Business Research, 67(1), 2891-2902.

https://doi.org/10.1016/j.jbusres.2012.06.004

Cohen, J., Cohen, P., West, S.G., \& Aiken, L.S. (2003). Applied multiple regression/correlation analysis for the behavioral sciences (3rd ed.). Mahwah, NJ, USA: Lawrence Erlbaum.

Correa, P.G., Fernandes, A.M., \& Uregian, C.J. (2010). Technology adoption and the investment climate: firm-level evidence for Eastern Europe and Central Asia. The World Bank Economic Review, lhp021. https://doi.org/10.1093/wber/lhp021

Chae, H.C., Koh, C.E., \& Prybutok, V.R. (2014). Information technology capability and firm performance: contradictory findings and their possible causes. MIS Quarterly, 38(1), 305-326.

https://doi.org/10.25300/MISQ/2014/38.1.14

Chatzoglou, P., Chatzoudes, D. (2016). Factors affecting e-business adoption in SMEs: an empirical research. Journal of Enterprise Information Management, 29(3), 327-358. https://doi.org/10.1108/JEIM-03-2014-0033

Chau, P.Y.K., \& Tam, K.Y. (1997). Factors affecting the adoption of open systems: An exploratory study. MIS Quarterly, 21(1), 1-24. https://doi.org/10.2307/249740

Chwelos, P., Benbasat, I., \& Dexter, A.S. (2001). Research Report: Empirical test of an EDI adoption model. Information Systems Research, 12(3), 304-321. https://doi.org/10.1287/isre.12.3.304.9708

De Haes, S., \& Van Grembergen, W. (2015). Enterprise governance of information technology. New York: Springer. https://doi.org/10.1007/978-3-319-14547-1

Fichman, R.G. (2001), The role of aggregation in the measurement of IT-related organizational innovation. MIS Quarterly, 25(4), 427-455. https://doi.org/10.2307/3250990

García-Moreno, M.B., García-Moreno, S., Nájera-Sánchez, J., \& Pablos-Heredero, C. De (2016). An explanatory model of the Organizational factors that explain the adoption of e-business. Journal of Industrial Engineering and Management, 9(2), 1 -35. https://doi.org/10.3926/jiem.1917

Grandon, E., \& Pearson J.M. (2004). Electronic commerce adoption: An empirical study of small and medium US businesses. Information \& Management, 42, 97-216. https://doi.org/10.1016/j.im.2003.12.010

Greene, P.G., Brush, C.G., \& Brown, T.E. (2015). Resources in small firms: an exploratory study. Journal of Small Business Strategy, 8(2), 25-40.

Hoffmann, J.P. (2004). Generalized linear models: An applied approach. Boston, USA: Pearson. 
Hong, W., \& Zhu, K. (2006). Migrating to internet-based e-commerce: Factors affecting e-commerce adoption and migration at the firm level. Information \& Management, 43, 204-221. https://doi.org/10.1016/j.im.2005.06.003

Hosmer, D.V., Lemeshow, S.Jr., \& Sturdivant, R.X. (2013). Applied Logistic Regression. New Jersey, USA: John Wiley \& Sons. https://doi.org/10.1002/9781118548387

Hsu, P., Kraemer, K.L., \& Dunkle, D. (2006). Determinants of e-business use in U.S. firms. International Journal of Electronic Commerce, 10(4), 9-45. https://doi.org/10.2753/JEC1086-4415100401

Iacovou, C.L., Benbasat, I., \& Dexter, A.S. (1995). Electronic data interchange and small organisations: Adoption and impact of technology. MIS Quarterly, 19(4), 465-485. https://doi.org/10.2307/249629

Ifinedo, P. (2011). An empirical analysis of factors influencing internet/e-business technologies adoption by SMEs in Canada. International Journal of Information Technology \& Decision Making, 10 (4), 731-766.

https://doi.org/10.1142/S0219622011004543

Jarvenpaa, S.L., \& Ives, B. (1991). Executive involvement and participation in the management of information technology. MIS Quarterly, 15(2), 205-227. https://doi.org/10.2307/249382

Jeston, J., \& Nelis, J. (2014). Business process management. London: Routledge.

Kaufman, L., \& Rousseeuw, P.J. (2005). Finding groups in data. An introduction to cluster analysis. New Jersey, USA: John Wiley \& Sons.

Kerzner, H.R. (2013). Project management: a systems approach to planning, scheduling, and controlling. New York: John Wiley \& Sons.

Kowtha N.R., \& Choon, T.W.I. (2001). Determinants of website development: A study of electronic commerce in Singapore. Information \& Management, 3, 227-242. https://doi.org/10.1016/S0378-7206(01)00092-1

Lacity, M.C., \& Willcocks, L.P. (2012). Advanced Outsourcing Practice: Rethinking ITO, BPO and Cloud Services. London: Palgrave Macmillan.

Lin, C., Huang, Y., Jalleh, G., Liu, Y., \& Tung, M. (2010). An Exploratory Study of Factors Affecting Adoption and Implementation of B2B E-Commerce in Australian Health Care Organizations. International Journal of Electronic Commerce, 1(2), 77-96.

Lin, H.F., \& Lee, G.G. (2005). Impact of organizational learning and knowledge management factors on e-business adoption. Management Decision, 43(2), 171-188. https://doi.org/10.1108/00251740510581902

Lin, H.F., \& Lin, S.M. (2008). Determinants of e-business diffusion: A test of the technology diffusion perspective. Technovation, 28, 135-145. https://doi.org/10.1016/j.technovation.2007.10.003

Loh, L., \& Venkatraman, N. (1992). Determinants of information technology outsourcing: A cross-sectional analysis. Journal of Management Information Systems, 9(1), 7-24. https://doi.org/10.1080/07421222.1992.11517945

Lucchetti, R., \& Sterlacchini, A. (2004). The adoption of ICT among SMEs: Evidence from an italian survey. Small Business Economics, 23(2), 151-168. https://doi.org/10.1023/B:SBEJ.0000027667.55821.53

Mehrtens, J., Cragg, P.B, \& Mills, A.M. (2001). A model of Internet adoption by SMEs. Information \& Management, 39, 165-176. https://doi.org/10.1016/S0378-7206(01)00086-6

Molla, A., \& Licker, P.S (2005). eCommerce adoption in developing countries: A model and instrument. Information \& Management, 42, 877-899. https://doi.org/10.1016/j.im.2004.09.002

Norusis, M.J. (2007). SPSS 15.0 advanced statistical procedures companion. Upper Saddle River, New York, USA: Prentice Hall.

Nurmilaakso, J.M. (2008). Adoption of e-business functions and migration from EDI-based to XML-based e-business frameworks in supply chain integration. International Journal of Production Economics, 113, 721-733. https://doi.org/10.1016/j.ijpe.2007.11.001 
Orme, J.G., \& Combs-Orme, T. (2009). Multiple regression with discrete dependent variables. New York, USA: Oxford University Press. https://doi.org/10.1093/acprof:oso/9780195329452.001.0001

Padrón-Cantú, E., Molina-Morejón, V.M., \& Méndez-Wong, A. (2014). E-Commerce Management Impact in Business Performance. Revista Global de Negocios, 2(3), 113-123.

Park, J.G., \& Lee, J. (2014). Knowledge sharing in information systems development projects: Explicating the role of dependence and trust. International Journal of Project Management, 32(1), 153-165.

https://doi.org/10.1016/j.ijproman.2013.02.004

Patil, S.K., \& Kant, R. (2014). A hybrid approach based on fuzzy DEMATEL and FMCDM to predict success of knowledge management adoption in supply chain. Applied Soft Computing, 18, 126-135.

https://doi.org/10.1016/j.asoc.2014.01.027

Poppo, L., \& Zenger, T. (1998). Testing alternative theories of the firm: Transaction cost, knowledge-based, and measurement explanations for make-or-buy decisions in information services. Strategic Management Journal, 19 , 853-877. https://doi.org/10.1002/(SICI)1097-0266(199809)19:9<853::AID-SMJ977>3.0.CO;2-B

Powell, T.C., \& Dent-Micallef, A. (1997). Information technology as competitive advantage: The role of human, business and technology resources. Strategic Management Journal, 18(5), 375-405. http://dx.doi.org/10.1002/ (SICI)1097-0266(199705)18:5\%3C375::AID-SMJ876\%3E3.0.CO;2-7

Porter, M.E. (1985). Competitive Advantage: Creating and sustaining superior performance. New York, USA: Free Press.

Premkumar, G., \& Ramamurthy, K. (1995). The role of interorganizational and organizational factors on the decision mode for adoption of interorganizational systems. Decision Sciences, 26, 3, 303-336.

https://doi.org/10.1111/j.1540-5915.1995.tb01431.x

Purvis, R.L, Sambamurthy, V., \& Zmud, R. (2001). The assimilation of knowledge platforms in organizations: An empirical study. Organization Science, 12(2), 117-135. https://doi.org/10.1287/orsc.12.2.117.10115

Ranganathan, C., Dhaliwai, J.S., \& Teo, T.S.H. (2004). Assimilation and diffusion of web technologies in supply-chain management: An examination of key drivers and performance impacts. International Journal of Electronic Commerce, 9(1), 127-161.

Rodríguez-Ardura, I., Meseguer-Artola, A., \& Vilaseca-Requena, J. (2007). Sistemas de venta en línea: un análisis de los factores críticos para el pequeño comerciante. Journal of Information Systems and Technology Management, 4(1), 95-108. http://dx.doi.org/10.4301/S1807-17752007000100005

Saboniene, A. (2015). Lithuanian export competitiveness: comparison with other Baltic States. Engineering Economics, $62(2), 49-57$.

Soliman, K.S., \& Janz, B.D. (2004). An Exploratory Study to Identify the Critical Factors Affecting the Decision to Establish Internet-based Interorganizational Information Systems. Information \& Management, 41(6), 697-706. https://doi.org/10.1016/j.im.2003.06.001

Stam, W., Arzlanian, S., \& Elfring, T. (2014). Social capital of entrepreneurs and small firm performance: A meta-analysis of contextual and methodological moderators. Journal of Business Venturing, 29(1), 152-173. https://doi.org/10.1016/j.jbusvent.2013.01.002

Subramanian, N., Gunasekaran, A., Yu, J., Cheng, J., \& Ning, K. (2014). Customer satisfaction and competitiveness in the Chinese E-retailing: Structural equation modeling (SEM) approach to identify the role of quality factors. Expert Systems with Applications, 41(1), 69-80. https://doi.org/10.1016/j.eswa.2013.07.012

Tan, J., Tyler, K., \& Manica, A. (2007). Business-to-business adoption of eCommerce in China. Information \& Management, 44, 332-351. https://doi.org/10.1016/j.im.2007.04.001

Teo, T.S.H, Tan, M., \& Wong K.B. (1998). A contingency model of Internet adoption in Singapore. International Journal of Electronic Commerce, 2(2), 95-118. https://doi.org/10.1080/10864415.1997.11518310 
Teo, T.S.H. (2007). Organizational characteristics, modes of Internet adoption and their impact: A Singapore perspective. Journal of Global Information Management, 15(2), 91-117. https://doi.org/10.4018/jgim.2007040104

Thong, J.Y.L. (1999). An integrated model of information systems adoption in small businesses. Journal of Management Information Systems, 4(15), 187-214. http://dx.doi.org/10.1080/07421222.1999.11518227

Tong, C., Tak, W.I.W., \& Wong, A. (2015). The Impact of knowledge sharing on the relationship between organizational culture and Job satisfaction: The perception of information communication and technology (ICT) practitioners in Hong Kong. International Journal of Human Resource Studies, 5(1), 19-47. https://doi.org/10.5296/ijhrs.v5i1.6895

Vilaseca, J., Torrent, J., Meseguer, A., \& Rodriguez, I. (2007). An integrated model of adoption and extent of e-commerce in firms. International Advances in Economic Research, 13(2), 222-241. https://doi.org/10.1007/s11294-0069061-z

Vladimirov, Z. (2015). Factors for the e-business adoption by small tourism firms and the role of shadow economic practices. European Journal of Tourism Research, 10, 5-34.

Wang, Y., \& Ahmed, P.K. (2008). The moderating effect of the business strategic orientation on eCommerce adoption: Evidence from UK family run SMEs. Journal of Strategic Information System, 18, 16-30. https://doi.org/10.1016/j.jsis.2008.11.001

Williams, W.T., \& Lambert J.M. (1959). Multivariate methods in plant ecology: I. Association-analysis in plant communities. Journal of Ecology, 47(1), 83-101. https://doi.org/10.2307/2257249

Xu, S., Zhu, K., \& Gibbs, J. (2004). Global technology, local adoption: A cross-country investigation of Internet adoption by companies in the United States and China. Electronic Markets, 14(1), 13-24. http://dx.doi.org/10.1080/1019678042000175261

Yusuf, Y.Y., Gunasekaran, A., Musa, A., Dauda, M., El-Berishy, N.M., \& Cang, S. (2014). A relational study of supply chain agility, competitiveness and business performance in the oil and gas industry. International Journal of Production Economics, 147, 531-543. https://doi.org/10.1016/j.ijpe.2012.10.009

Zhou, T. (2011). Examining the critical success factors of mobile website adoption. Online Information Review, 35(4), 636-652. https://doi.org/10.1108/14684521111161972

Zhu, K., Kraemer, K., \& Xu, S. (2003). Electronic business adoption by European firms: A cross-country assessment of the facilitators and inhibitors. European Journal of Information Systems, 12(4), 251-268. https://doi.org/10.1057/palgrave.ejis.3000475

Zhu, K., Kraemer, K.L., \& Xu, S. (2006). The process of innovation assimilation by firms in different countries: A technology diffusion perspective on e-business. Management Science, 52(10), 1557-1576. https://doi.org/10.1287/mnsc.1050.0487

Journal of Industrial Engineering and Management, 2018 (www.jiem.org)

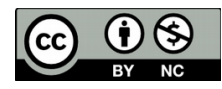

Article's contents are provided on an Attribution-Non Commercial 4.0 Creative commons International License. Readers are allowed to copy, distribute and communicate article's contents, provided the author's and Journal of Industrial Engineering and Management's names are included. It must not be used for commercial purposes. To see the complete license contents, please visit https://creativecommons.org/licenses/by-nc/4.0/. 